Research paper

\title{
Confined carbonates - Regional scale hydraulic interaction or isolation?
}

\author{
Judit Mádl-Szőnyi a, *, Brigitta Czauner a, Veronika Iván ${ }^{a}$, Ádám Tóth ${ }^{a}$, Szilvia Simon ${ }^{\text {a }}$, \\ Anita Erőss ${ }^{a}$, Petra Bodor a, Tímea Havril ${ }^{a}$, László Boncz ${ }^{\text {b }}$, Viktor Sőreg ${ }^{b}$ \\ a József and Erzsébet Tóth Endowed Hydrogeology Chair, Department of Physical and Applied Geology, Faculty of Science, Eötvös Loránd University, 1/C \\ Pázmány P. stny. Budapest-1117, Hungary \\ ${ }^{\mathrm{b}}$ MOL Hungarian Oil and Gas Public Limited Company, 18 Oktober 23. St. Budapest-1117, Hungary
}

\section{A R T I C L E I N F O}

\section{Article history:}

Received 29 February 2016

Received in revised form

30 May 2017

Accepted 5 June 2017

Available online $\mathrm{xxx}$

\section{Keywords:}

Confined carbonates

Hydraulics

Gravity-driven groundwater flow

Salinity distribution

Underpressure

\begin{abstract}
A B S T R A C T
This study examines the patterns of groundwater flow and salinity in a region of confined basement carbonate aquifer along with the region's unconfined adjacent part and siliciclastic confining strata. An understanding of regional-scale flow patterns in this setting may prompt a rethinking of the traditional view. According to that view confined carbonates are bounded and isolated by impermeable confining layers from their surroundings. A basin-scale analysis of the subsurface conditions promises better to accentuate otherwise unseen signs of hydraulic communication both horizontally and vertically between different parts of the flow domain. This study reveals that various flow regimes exist, in the area of the Paleogene Basin, Hungary. The pattern and intensity of these flow regimes depend on the elevation of basement carbonates and the structures, thickness, hydraulic conductivity and heterogeneity of the covering layers. Effects of gravity-driven regional groundwater flow were identified down to an elevation of $-500 \mathrm{~m}$ asl including recharge and discharge areas. Hydraulic communication occurs both vertically and laterally in this zone but the direction and intensity of flow are influenced by aquitards or confining layers. Nevertheless, hydraulic boundaries (a colinear ridge in the north and a sink in the south) were recognized in the study area. This impedes horizontal hydraulic communication between the shallower unconfined-to confined carbonates in the west and the deeper confined carbonates in the east. Southeasterly through-flow can be observed below $-500 \mathrm{~m}$ asl elevation which terminates in a regionally underpressured zone due to a regional aquitard in the zone of uplift. Both underpressured and overpressured blocks bounded by faults appear to influence vertical connections between siliciclastic confining layers and carbonates in the vicinity of significant strike-slip faults. The flow regimes thus recognized affect the subsurface salinity pattern, and hydrocarbon migration and as a result the planning of geothermal exploration. Consequently, a priori assumption of impermeability of confining layers and hydraulically isolated carbonate compartments below seems to be an oversimplification.
\end{abstract}

(c) 2017 Elsevier Ltd. All rights reserved.

\section{Introduction and objectives}

Deeply buried carbonate units in foreland basinal settings overlain by thick successions of siliciclastic sediments are prospective sites for hydrocarbon and geothermal exploration (Goldscheider et al., 2010). However, the exploration of these deep areas is expensive, and is further complicated by tectonic conditions which make seismic data acquisition difficult, as well as

\footnotetext{
* Corresponding author.

E-mail address: szjudit@ludens.elte.hu (J. Mádl-Szőnyi).
}

resulting in highly heterogeneous reservoir quality (Allen et al., 2014). In addition, the hydraulic conditions occurring in confined carbonate units are difficult to characterize due to the general lack of data. Taken together, these factors result in a high degree of uncertainty that places exploration for various potential economic resources at risk. Confined carbonate units are traditionally considered to be aquifer systems hydraulically independent of their siliciclastic cover. This is due to the widely accepted view, that the confining layers are generally deemed to be impermeable at least in relation to the underlying carbonate aquifers. The existence of sealbounded compartments also appears in the literature of petroleum geology (Hunt, 1990), but it was already criticized by Tóth et al. 
(1991) when it was introduced.

The nature of the connection between deep confined carbonate units and adjacent unconfined gravity-driven regional groundwater flow (GDRGF) (Tóth, 1962, 1963) is poorly understood. The very first study by (Mádl-Szőnyi and Tóth, 2015) in this area examined the flow systems present in unconfined and the marginal areas of confined carbonate settings adapting the Tóthian-flow pattern to these cases. Geologically transient flow conditions were revealed where a confined carbonate aquifer in a zone of uplifting morphological settings is reflected in the subhydrostatic pore pressures (Mádl-Szőnyi et al., 2015). The modified GDRGF pattern (Mádl-Szőnyi and Tóth, 2015), along with a consideration of other driving forces (such as buoyancy) within the framework of the geological evolution of the area was later used as a working hypothesis for the numerical understanding of the evolution of hydrodynamics for marginal areas of unconfined and confined carbonate aquifer systems (Havril et al., 2016). The first complex hydraulic data evaluation based on the above mentioned principles was carried out in the dominantly unconfined Buda Thermal Karst (BTK) area on the west bank of the Danube by Erhardt et al. (2017). This revealed transparently flow pattern representing GDRGF systems in this geologically complex area. In addition, fluid potential anomalies caused by faults and lithological heterogeneities were identified in the uppermost part of the flow field. A comprehensive knowledge of secondary hydrocarbon migration and geothermal exploration (production and injection) possibilities (Mádl-Szőnyi and Simon, 2015) for these areas linked to the hydraulics is, however, still required.

In the present study the main aim is the application of GDRGF concepts based on data analyses to a confined deep carbonate aquifer system which is, in turn, connected to adjacent unconfined regions. Here, the emphasis will be on understanding the karstified carbonate rock matrix (unconfined and confined) and its hydraulic relation with siliciclastic confining strata (with extensive aquitards and aquifers) as a whole. In this way, it is hoped that an understanding of regional scale flow patterns for these settings may be obtained and an answer be provided to the question of how unconfined and confined settings are connected. Besides the hydraulic character of an area its salinity pattern can also reflect the nature of the interaction between confined carbonates and their covering siliciclastic formations. The mixing of fresh and more saline formation waters at geological scales has been demonstrated to be the phenomenon most strongly influencing the chemistry of evolving natural groundwater along flow paths (Schwartz and Zhang, 2003). This process in sedimentary basins may be connected to uplift, where meteoric water infiltration may flush units which had previously contained, more saline formation waters. In this context the term "formation water" (Schwartz and Zhang, 2003) lacks a sufficiently strict definition of the origin of the saline water. The interpretation of salinity in the context of GDRGF hydraulics can therefore assist in the determination of the degree of replenishment of formation waters by fresh water and can help to understand the flow pattern of the system.

The study area is located in the Pannonian Basin of central Hungary, and is delineated by the EOV coordinates: EOVX: 200 000-280 000, EOVY: $610000-720000$. (EOV is the Hungarian National Grid, a transverse Mercator projection, in which a positive $\mathrm{X}$ indicates north and positive $\mathrm{Y}$ east. The numbers refers to meters) (Fig. 1). It contains the eastern edge of the partly unconfined karst area of the Transdanubian Range and an adjoining confined carbonate aquifer system in the east. The latter is a segment of the Hungarian Paleogene Basin (Báldi and Báldi-Beke, 1985), in which the Pre-Cenozoic formations are largerly covered by Paleogene formations associated with the Paratethys Sea (Fig. 1a and b).

Based on these preliminary considerations, the detailed objectives of this paper are i) to understand the regional flow pattern in the region; ii) to reveal the hydraulic interrelationships between siliciclastic confining layers and carbonate aquifer systems; and iii) to examine the salinity character of fluids to understand the interacting processes. The question of the study is whether the confining layers and the deep carbonate system are insulated (due to impermeability of confining layers) or connected both vertically (due to the leaky nature of confining formations) and horizontally (to unconfined aquifers). The answer to this question depends on the analyses of measured hydraulic and salinity data in wells and will be numerically validated. The results may help to understand the availability of geothermal fluids better and to reveal migration processes of hydrocarbons. Additionally, it should help to explain geochemically induced deep karstification processes.

\section{Geological and hydraulic settings}

\subsection{Topography and climate}

The study area is characterized by the complex topography to be found in the surroundings of Budapest (Fig. 1b and c). The uplifted regions of the Transdanubian Range are represented by the Buda Hills (559 m), and Pilis (756 m) to the west of the River Danube. In addition, to the east, on the opposite bank of the river, the Pest plateau (average elevation $210 \mathrm{~m}$ ), the foothills of the North-Hungarian Mountain Range named the Gödöllö Hills (344 m) and the NW areas of the Great Hungarian Plain (lowest elevation: $88 \mathrm{~m}$ ) are included in the examination. This complex area is a transition zone between lowlands and highlands, with correspondingly variable climatic elements. The annual mean temperature is $9.5-10{ }^{\circ} \mathrm{C}$ and annual rainfall is 500-600 mm (Marosi and Somogyi, 1990; Mersich, 2000).

\subsection{Geological and structural settings}

Geologically, the Pannonian Basin is a back-arc basin almost completely surrounded by Alpine-Carpathian-Dinaric orogens (Fig. 1 a). The extensional formation of the basin started in the Early Miocene, whereas its structural reactivation (inversion) took place over a period from the Late Miocene up to recent times (Horváth and Cloetingh, 1996; Bada et al., 2007). The Pre-Neogene basement of the study area is divided into three different tectonostratigraphic mega-units (terranes) (Fig. 2a; Csontos et al., 1992; Kovács et al., 2010). In the north-northwest, the ALCAPA (Csontos and Vörös, 2004) mega-unit is found, consisting of the Eastern Alps, the Western Carpathians and the Transdanubian Range, whereas the Tisza mega-unit lies in the south-southeast (Fig. 2b). Between them a tectonostratigraphic unit is the Mid-Hungarian Mega-unit (MHMU) (Fig. 2a) or Mid-Hungarian Shear Zone (Schmid et al., 2008; Haas et al., 2010), which is bounded by SW-NE trending fault zones: the Balaton-Tóalmás Line to the north and the MidHungarian Line to the south (Fig. 2a). Lithologically, the Transdanubian Range is characterized by slightly metamorphosed Variscian formations, overlain by non-metamorphosed Alpine sequences from the Middle and Late Triassic to Early Jurassic, with limestones and dolomites, marls and cherty limestones forming the bulk of the range (Wein et al., 1977; Haas et al., 2000) (Fig. 1c). The Mid-Hungarian Mega-unit (MHMU) is a very complex imbricated system. At the study area it is characterized by Middle Triassic limestones, brecciated limestones (Bauer et al., 2016) and deepwater siliceous shales and sandstones, plus basalts (Haas et al., 2010; Haas, 2012). In the Tisza Mega-unit high grade crystalline basement rocks coupled with Late Variscian granites (Buda, 1995) form the substratum of a non-metamorphosed Mesozoic sequence. 

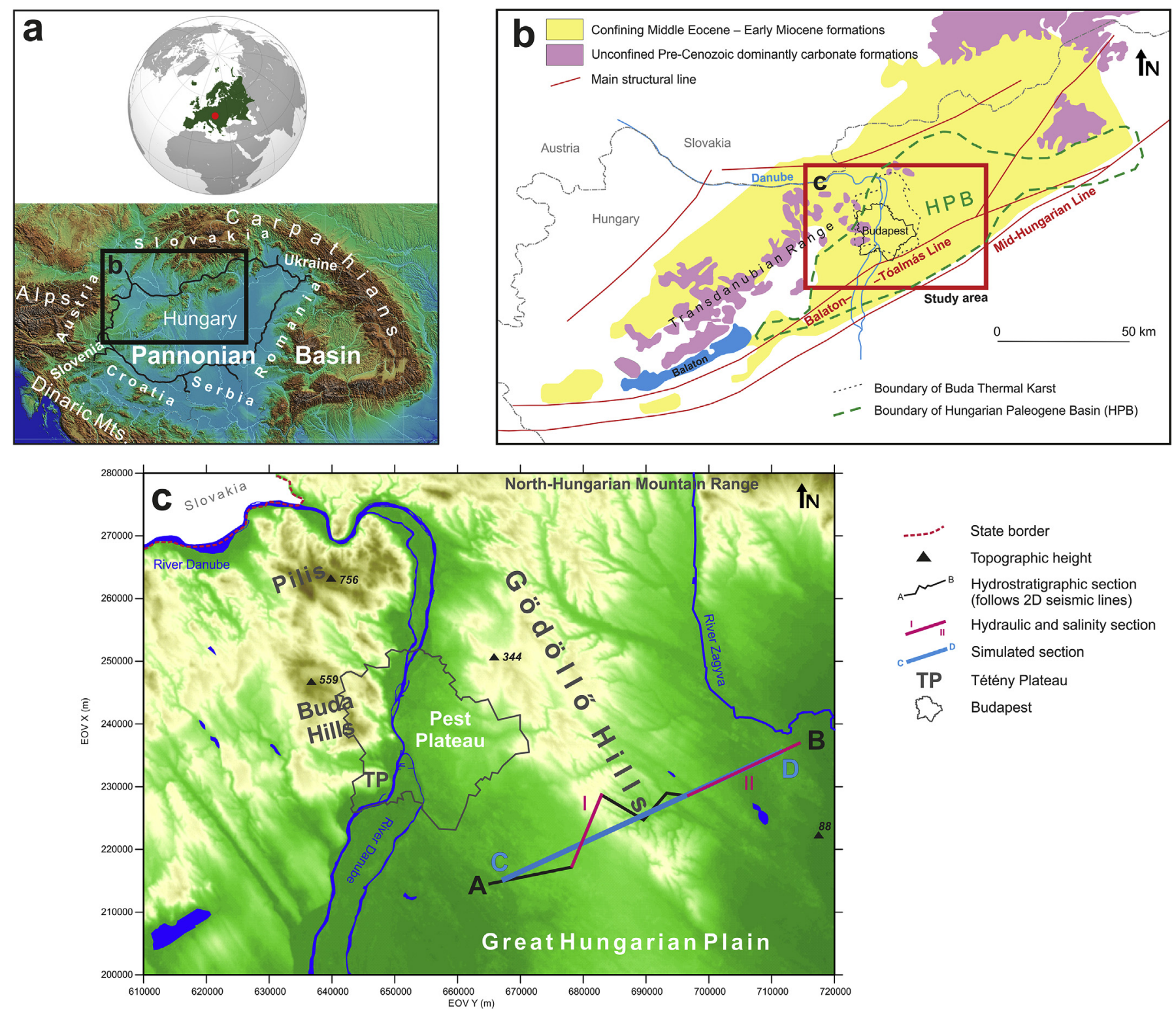

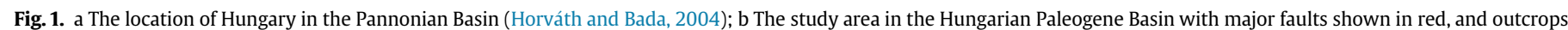
of Pre-Cenozoic formations indicated by purple (modified from Tari et al. (1993), and Haas (2012)); c The topographic features of the study area.

The present elevation of the Pre-Cenozoic basement can be found between the ground surface and $-500 \mathrm{~m}$ asl elevation in the west of the Danube, gradually deepening eastwards reaching more than $-4000 \mathrm{~m}$ asl elevation in south and the east of the study area (Haas et al., 2010) (Fig. 2b).

During the Paleogene, an eastward movement and amalgamation of the ALCAPA and Tisza units along the Mid-Hungarian Line occurred. The Hungarian Paleogene Basin (Fig. 1b) evolved as a retroarc flexural basin (Tari et al., 1993). The thrust load resulted in a generally deep, underfilled basin during the Middle Eocene Early Oligocene. In the Late Eocene, terrestrial siliciclastic rocks, shallow-water limestone, and deep-water marl overlain by Oligocene anoxic and, later, well-aerated deep marine shales were deposited (Báldi and Báldi-Beke, 1985). In the Late Oligocene to Early Miocene the basin reached an overfilled stage, filling up with shallow marine to continental siliciclastics (Table 1 ).

The rifting of the Pannonian Basin started in the Early Miocene (Royden et al., 1982; Royden and Horváth 1988), and this was superimposed on the earlier Paleogene Basin complex in the study area (Royden et al., 1982; Tari et al., 1992). As a result, a network of predominantly NE-SW trending fault zones evolved in this period (Rumpler and Horváth, 1988; Tari et al., 1992; Balázs et al., 2016). The Early and Middle Miocene formations are dominantly marine siliciclastics, but shallow marine limestones, and a very thick series of volcanics and volcanoclastics also occur (Table 1). During the Late Miocene Pliocene, post-rift thermal subsidence of the Pannonian Basin (Horváth and Royden, 1981; Royden et al., 1982) took place. The basin was occupied by the isolated Lake Pannon with a stable brackish salinity of $8-15 \%$ (Magyar et al., 1999) and this was gradually filled up by sediments derived from the uplifting Alps and Carpathians. The stratigraphic subdivision of the resulting deep to shallow lacustrine to alluvial sedimentary succession was based on the lithofacies (Gajdos et al., 1983) of the system, represented by deep water marls, turbidite, sandstones, slope shales, and lithologically variable deltaic deposits overlain by an alluvial suit (Bérczi and Phillips, 1985; Juhász et al., 2007; Sztanó et al., 2013, 2016). 

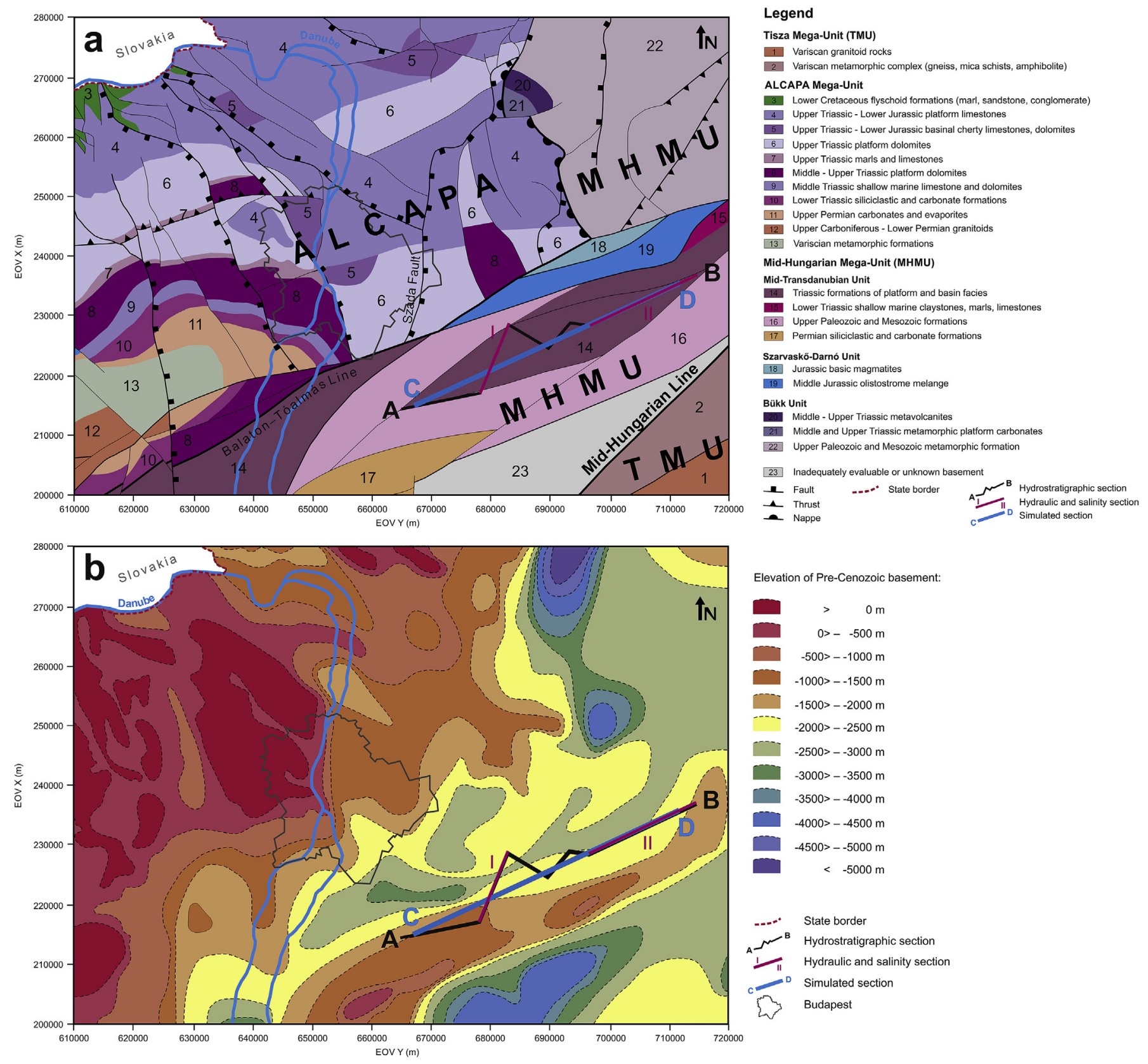

Fig. 2. a The Pre-Cenozoic basement of the study area (based on Haas et al., 2010); b The elevation of the Pre-Cenozoic basement of the study area (based on Haas et al., 2010).

The gradual inversion of the basin started in the Late Miocene (Bada et al., 2007; Uhrin, 2011). Uplifting began in the western part of the Pannonian Basin and has continued over the last 3 million years in the Gödöllö Hills (Uhrin and Sztanó, 2007). At the same time subsidence has continued in the low-lying plain areas (Horváth and Cloetingh, 1996; Ruszkiczay-Rüdiger et al., 2005, 2006). The Balaton-Tóalmás strike-slip fault reactivated and its activity continued during the neotectonic phase as well (Magyar et al., 1999; Bada et al., 2007). The Quaternary sediments deposited on the eroded surface of Pliocene sands and clays are represented by alluvial gravel, sand, clay, aeolian sand and loess (Körössy, 2004). The inversion manifested by the uplift of the Transdanubian Range is indicated by among others Pleistocene travertine horizons especially in the Buda Hills (Wein et al., 1977; Ruszkiczay-Rüdiger et al., 2005; Kele et al., 2011) and karstification processes (Leél-Őssy, 1995; Erőss, 2010).

\subsection{Hydrocarbon systems}

Hydrocarbon systems evolved predominantly to the east of the Danube. The principal reservoirs are the Triassic limestones and Jurassic formations of the Pre-Cenozoic basement, as well as Eocene limestone, sandstones and tuffs (Table 1). The structural, stratigraphic and combined traps are thought to have been charged from Paleogene source rocks (Dolton, 2006) such as the euxinic clay, clay-marl and marl of Late Eocene and Early Oligocene, and the Early Oligocene anoxic clay (average TOC content $0.5-1.0 \%$ ) (Table 1$)$. Due to the high basal heat flow of the study area (90-115 $\mathrm{mW} / \mathrm{m}^{2}$ ) (Dövényi and Horváth, 1988) the Paleogene source rocks are considered to be currently in the oil window (Badics and Vetö, 2012; Boncz et al., 2012; Poros et al., 2012). Due to the limited horizontal and vertical (max. $500 \mathrm{~m}$ ) migration, it is suggested that only reservoirs in direct contact with the source 
Table 1

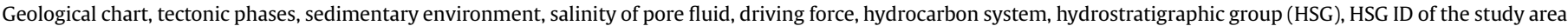
(compiled based on Haas et al. (2010); Horváth (2007); Dolton (2006); Boncz (2004); Martinecz (2014)).

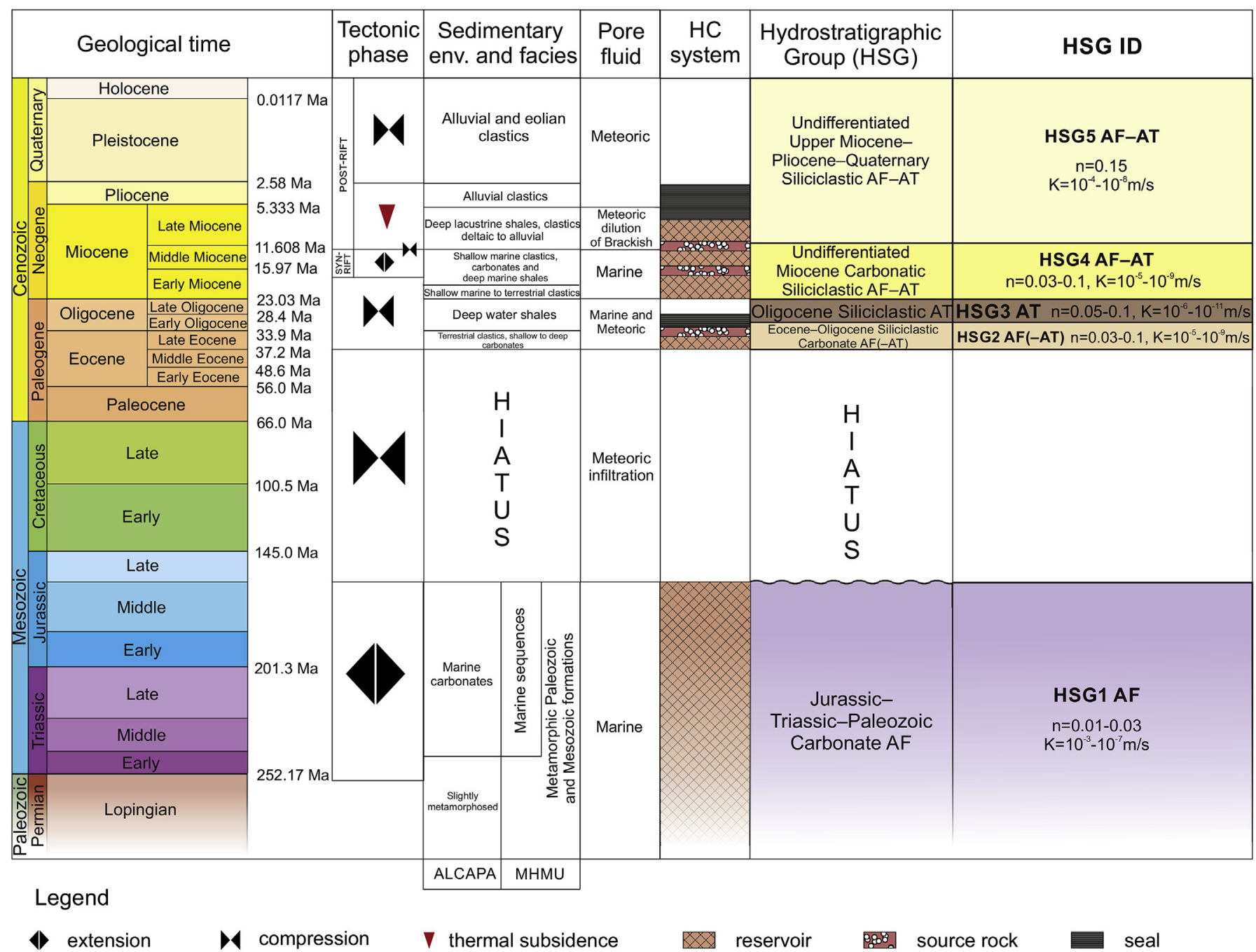

rocks are considered as prospective (Boncz et al., 2012). Others have suggested that the location, extent and morphology of the traps are influenced by secondary migration due to regional hydraulic conditions (Boncz et al., 2012). The main seals are low-permeablity rocks of Eocene and Oligocene (Table 1).

\subsection{Hydrogeological overview}

The hydrogeological conditions over the mentioned geological settings are also influenced by a major first order unconformity dividing Triassic carbonate aquifers from Paleogene clastics (aquitards) and Eocene limestones (aquifers). However, there are normal, reverse and strike-slip faults in the area which influence both the carbonates and the clastics (Table 1). Based on a preliminary pressure interpretation (derived from individual pressure measurements in hydrocarbon wells) it was found that basement and connected Eocene aquifers are characterized by close to hydrostatic pressure conditions (Boncz, 2004). The outcrops of these formations with overlying layers of limited thickness (Fig. 2b) are to be found predominantly to the west of the Danube (Fig. 1b) and contain karst water of various temperature (up to $60{ }^{\circ} \mathrm{C}$ ) and salinity (up to $1700 \mathrm{mg} / \mathrm{l}$ ) (Papp, 1942). The overlying hydrogeological unit of the area was defined by the dominantly siliciclastic Oligocene and Miocene rocks, which were thought to function as an aquitard. East of the River Danube, above the deepest carbonate unit, these formations are also characterized by close to hydrostatic pressure (Boncz, 2004). The overlying unit is comprised of limited carbonatic aquifers from the Middle Miocene. The uppermost unit consists of siliciclastic Upper Miocene, Pliocene and Quaternary strata. These formations in the confined carbonate area are also characterized by dominantly hydrostatic pressure, though in some places slight overpressure is observed (Boncz, 2004).

Various groundwaters in the Pre-Cenozoic basement south of the Balaton-Tóalmás Line were found to be dominantly of $\mathrm{NaCl}$ type, and $\mathrm{Ca}-(\mathrm{Mg})-\mathrm{HCO}_{3}$-type to the north. The chemistry of the water in the Eocene limestone varies from the $\mathrm{Ca}-(\mathrm{Mg})-\mathrm{HCO}_{3}$ to $\mathrm{Na}-\mathrm{Ca}-\mathrm{HCO}_{3}$-type in deeper locations (Zilahi-Sebess, 2011; Zilahi-Sebess and Gyuricza, 2012). The dominantly siliciclastic Oligocene and Miocene formations are also characterized by basically NaCl-type water (Kiss et al., 1999; Boncz, 2004). This, however, changes depending on depth and lithology. The low permeability Oligocene formations are of the NaCl-type and can contain 
40,000-60,000 $\mathrm{mg} / \mathrm{l}$ dissolved solids. In the low permeability Miocene formations at a similar depth, the TDS can vary from 20,000 to $40,000 \mathrm{mg} / \mathrm{l}$, and these are also of the NaCl-type (ZilahiSebess and Gyuricza, 2012).

The average geothermal gradient for the eastern confined carbonate area is $\sim 41,5{ }^{\circ} \mathrm{C} / \mathrm{km}$ (Dövényi and Horváth, 1988). The highest water temperature in the basement formations is $\sim 155{ }^{\circ} \mathrm{C}$ and may be influenced by heat convection as well (Zilahi-Sebess and Gyuricza, 2012). In summary, the preliminary studies display basically hydrostatic pressure conditions and very diverse salinity and water chemistry in the different formations of the study area.

\section{Data and methods}

The characterization of the flow patterns for the study area began by grouping of geological formations into hydrostratigraphic units based on their regional hydraulic conductivity. Subsequently, the fluid flow systems of the study area were characterized by the analysis of hydraulic head and salinity data derived from water and hydrocarbon wells before production had commenced (preproduction data analysis).

\subsection{Database and data processing}

The database of the study area was constructed from data obtained from about 5800 hydrocarbon and water wells (ground surface down to $-2800 \mathrm{~m}$ asl elevation). The basic, hydraulic (pore/ formation pressure), and water chemical data of the hydrocarbon wells were placed at our disposal by MOL the Hungarian Oil and Gas Company, while data from water wells were collected from the original (paper-based) well records, available from the archives of the Mining and Geological Institute of Hungary.

In the course of data culling the reliability of individual data were checked. 74 hydraulic data were left out on account of technical problems rendering data are unreliable. Chemical data were only available from about 500 wells and of these data, only those referring to total dissolved solid content were used. However, data were screened for their ion balance, and only those where the ion balance error $\leq 5 \%$ were used (in the case of 78 chemical data).

Among the well data, the hydraulic and water chemical data required significant preparation before interpretation. After culling, the hydraulic head $(h)$ was calculated using both types of hydraulic data. In the case of formation pressure data, $h$ was determined using Hubbert's fluid-potential equation (Hubbert, 1940):

$h=z+p /(\rho \cdot g)$

where $h$ is the hydraulic head $[\mathrm{L}], z$ the elevation above the datum plane $[\mathrm{L}], p$ the gauge pressure $\left[\mathrm{M} / \mathrm{LT}^{2}\right], \rho$ the density of water $[\mathrm{M} /$ $\left.\mathrm{L}^{3}\right], g$ the gravitational acceleration $\left[\mathrm{L} / \mathrm{T}^{2}\right]$. It should be mentioned here that the use of constant density is relevant to regional hydraulic studies in the mapping of the fluid potential field (Tóth, 2009). Though this approach for deriving hydraulic head can cause an error in the resulting values for variable temperature and high salinity waters. These errors could be neglected at the scale(s) of the present study. Considering that temperature and salinity have opposite effects on density, the use of $1000 \mathrm{mgL}^{-1}$ density was proved to be reasonable in the study area. On the other hand, since the reliability of hydrochemical data is lower, and also as the number of measured parameters is variable in the samples, only the TDS (total dissolved solid) was used.

\subsection{Basin-scale hydraulic and salinity analysis}

The principles of the basin-scale hydraulic approach were applied, as summarized and modified from Tóth (2009), Verweij et al. (2012), Czauner and Mádl-Szőnyi (2013), and Mádl-Szőnyi and Simon (2015) etc. In the portrayal of fluid flow systems, potentiometric maps were compiled. Contrary to traditional hydrogeological approaches, the basin-scale hydraulic approach treats the flow field (including aquifers and aquitards) as a whole based on the principle of hydraulic continuity (Tóth, 1995, 2009). In the course of the evaluation the fluid potential values (i.e. hydraulic heads) are mapped in the form of so-called tomographic potentiometric map series. These are compared with the surface topography (i.e. the topographic driving force) and with the geology (i.e. hydrostratigraphy) characteristic of the individual tomographic slices in order to reveal their influence on the flow distribution. The flow field is dissected by virtual horizontal planes representing different elevation intervals, depending on the vertical data distribution of measuring points of hydraulic head or pressure data (cross counted with hydraulic head data) for the study area. The elevation ranges (ER) were as follows: ground surface $-100 \mathrm{~m}$ asl; 100-0 $\mathrm{m}$ asl; $0-(-250) \mathrm{m}$ asl; $(-250)-(-500) \mathrm{m}$ asl; $(-500)-$ $(-1000) \mathrm{m}$ asl $;<(-1000) \mathrm{m}$ asl. Potentiometric maps are constructed from hydraulic head data by measuring point elevations between two successive planes. These represent lateral fluid flow directions based on equipotentials compiled from hydraulic head data. The flow path is perpendicular to the equipotentials, along which the value of fluid potential is constant. The horizontal direction of fluid flow tends from higher equipotential towards the lower. Vertical flow directions may also be derived from the comparison of successive planes. Therefore, potentiometric maps are suitable for the examination of not only horizontal but also vertical fluid flow.

Geoinformatical data processing and interpretation was carried out using ArcMap 10.2 and Surfer 9 software (Environmental Systems Research Institute, 2014). Managing the available base maps and raw point data, the appropriate geodatabase was assembled. The measured potentiometric values and TDS values were sorted for each elevation range, and interpolated for the test area using the spline technique. This tool is a deterministic interpolation method using a minimum curvature spline technique. The process results in a surface which passes exactly through the measured input points. As such, it proved to be the most realistic estimation for the given data type and distribution.

A hydrostratigraphic section was derived (following 2D seismic lines) for the confined carbonate aquifer (see the trace line in Fig. 1c, 2a,b). The hydraulic data were processed and interpreted along two parts of the section (I and II) to understand the flow pattern. Along the sections not only the hydraulic heads (for water wells) but also the measured pressure values (for hydrocarbon wells) were used in the evaluation. The underground pressure pattern carries information concerning the pressure regimes (overpressured, hydrostatic or underpressured). In the course of the hydraulic analysis the extent of under- or overpressure is expressed by the dynamic pressure increment $(\Delta \mathrm{p})$ (Tóth, 2009). This is defined as the difference between static or nominal pressure ( $\left.p_{n o m}\right)$ and the dynamic or real pressure ( $p_{\text {real }}$ ) at a given elevation.

$\Delta \mathrm{p}=\mathrm{p}_{\mathrm{dyn}}-\mathrm{p}_{\mathrm{st}}=\mathrm{p}_{\mathrm{real}}-\mathrm{p}_{\mathrm{nom}}$

The different pressure regimes can be characterized by values higher than, equal to, or lower than hydrostatic pressure values. Pressure increments were displayed in hydrostratigraphic sections together with hydraulic head values as the function of elevation of the measuring point of the well. They were expressed in normalized form (\%) in the function of the nominal pressure (and were displayed in the elevation of the measuring point of the well).

In addition, water salinity values for different slices were 
compared parallel with the tomographic potential maps and the relevant geological (hydrostratigraphic) map slices. Salinity was evaluated using the TDS content of water and categorized as follows: fresh $<1000 \mathrm{mg} / \mathrm{l}$; brackish: $1000-10,000 \mathrm{mg} / \mathrm{l}$; saline: 10,000-100,000 mg/l (Deming, 2002). In this way hydraulic and salinity data could be interpreted in 3D in the frame of hydrostratigraphy on the regional scale. The salinity data were displayed in the sections (I, II) as well (Figs. 1 and 2).

\subsection{Validation by numerical simulation}

Finally, 2D numerical flow and heat transport simulations were carried out to check the validity of the derived fluid flow distribution and reveal the influencing processes. In the course of the numerical representation of flow patterns for the confined part of the study area, flow and heat transport simulations were performed. The simulations were carried out using Comsol Multiphysics (Zimmerman, 2006), a finite element program for the solution of numerical equations. The simulated scenarios were set up based on the conceptual model derived from the hydraulic and chemical data analyses for the confined study area.

\section{Results}

\subsection{Hydrostratigraphic groups and their spatial distribution}

On the one hand, hydrostratigraphy was evaluated based on a hydrostratigraphic classification of the geological column of water and hydrocarbon wells of the area (modified from Mádlné Szőnyi et al., 2013) (Table 1). The hydrostratigraphic and structural pattern of the confined part of the study area appears in a hydrostratigraphic cross section (Fig. 3, the location see in Figs. 1c and 2). On the other hand, the structures and hydrostratigraphy were displayed for the potentiometric slices from and below $100-0 \mathrm{~m}$ asl (Fig. 4a-4d) based on the seismic interpretations of MOL Plc and the hydrostratigraphic sections and maps of Mádlné Szőnyi et al. (2013). The hydrostratigraphic groups in the maps displayed are referred to the center of the slices. The faults interpreted by MOL were also displayed on the maps (Fig. 4a-d) and the section (Fig. 3). The original geological, structural and hydrostratigraphic maps and data are confidential, and were therefore not involved in the preparation of the database used in the present paper.

The very diverse formations of the area were evaluated in relation to each other in order to understand their functioning in operation of hydraulic systems on a regional scale. To achieve this goal the hydrogeological behaviour of geological formations was examined based on the collected dataset in individual studies (geological descriptions and pumping test data) (Mádlné Szőnyi et al., 2013; Garamhegyi, 2014; Martinecz, 2014). The hydrostratigraphic characterization of all individual units was evaluated for the whole study area in these studies. The individual units were classified into five regional scale hydrostratigrapic groups characterized by porosity and hydraulic conductivity values (Table 1). In keeping with the aims of this paper, only the derived hydrostratigraphic groups (HSGs) were displayed in section and on maps and discussed here (Table 1; Fig. 3; Fig. 4a-4d). The maps do not show the hydrostratigraphic groups for the NW part of the study area due to the lack of data.

The first hydrostratigraphic group is the Jurassic-TriassicPaleozoic metamorphic-magmatic-siliciclastic, dominantly carbonate aquifer (HSG1 AF). These rocks are fractured and were affected by erosion, weathering, and, particularly in the case of the carbonate formations by meteoric infiltration and exposed karstification from the Late Cretaceous to Early Eocene (Báldi and Báldiné Beke, 1985). Based on observations during drilling the upper $100 \mathrm{~m}$ thick zone of the Pre-Cenozoic basement is traditionally handled as a highly permeable (productive) zone due to its karstification. The evaluation of pumping test data from this zone yielded an average hydraulic conductivity of $\mathrm{K}=10^{-3}-10^{-5} \mathrm{~ms}^{-1}$ (Mádlné Szőnyi et al., 2013), but lower values also appear in Paleozoic formations of HSG1 AF (Table 1). The Eocene basal conglomerates are aquifers, the Eocene limestone and even the Eocene-Oligocene marl formations may be karstified. Thus the Eocene-Oligocene siliciclastic and carbonate rocks comprise an aquifer (-aquitard) (HSG2 AF(-AT)) group characterized by $\mathrm{K}=10^{-5}$ - $10^{-9} \mathrm{~ms}^{-1}$. These two groups form the dominantly carbonate aquifer system.

The third unit in the sequence is the Oligocene siliciclastic aquitard (HSG3 AT). This is the most pronounced aquitard sequence due to its thickness (from 80 to $100 \mathrm{~m}$ to about $1000 \mathrm{~m}$ ) and its regional extent in the study area. It is characterized by the lowest hydraulic conductivity, $\mathrm{K}=10^{-6}-10^{-11} \mathrm{~ms}^{-1}$, and it separates the lower aquifer system from the upper (Table 1 ).

The Lower and Middle Miocene formations are siliciclastic aquifers and aquitards with limited hydraulic conductivity $\left(\mathrm{K}=10^{-9} \mathrm{~ms}^{-1}\right)$. However, the carbonate formations, which are underrepresented in comparison to the siliciclastic ones, can be good aquifers $\left(\mathrm{K}=10^{-5} \mathrm{~ms}^{-1}\right)$. Therefore, these Miocene formations may be handled as an undifferentiated carbonatic and siliciclastic aquifer-aquitard group, HSG4 AF-AT. For the purposes of this research, the younger formations from the Late Miocene - Pliocene and Quaternary were handled as a whole. The lower part of the Upper Miocene formations are basically aquitards, the upper part of the Upper Miocene and Pliocene formations are good aquifers, similar to the Pleistocene layers. Therefore, these were classified as an undifferentiated Upper Miocene-Pliocene-Quaternary siliciclastic aquifer-aquitard (HSG5 AF-AT) $\left(\mathrm{K}=10^{-4}-10^{-8} \mathrm{~ms}^{-1}\right)$ (Table 1).

In the hydrostratigraphic map series (Fig. 4a-d) we can discern the lateral extent of these units. HSG1 and 2 are located close to the surface in the west of the Danube in Budapest (Fig. 4a-d) and on the south-western edge of the study area. The areal expansion of these two hydrostratigraphic groups increases with depth and reaches the greatest extent in the western part of the potentiometric slice

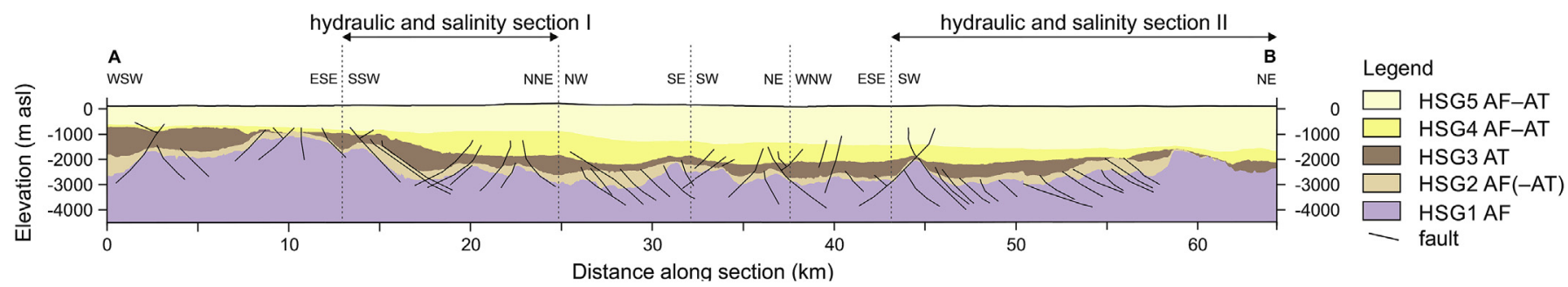

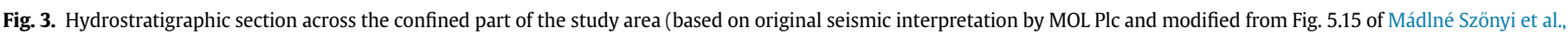
2013). 


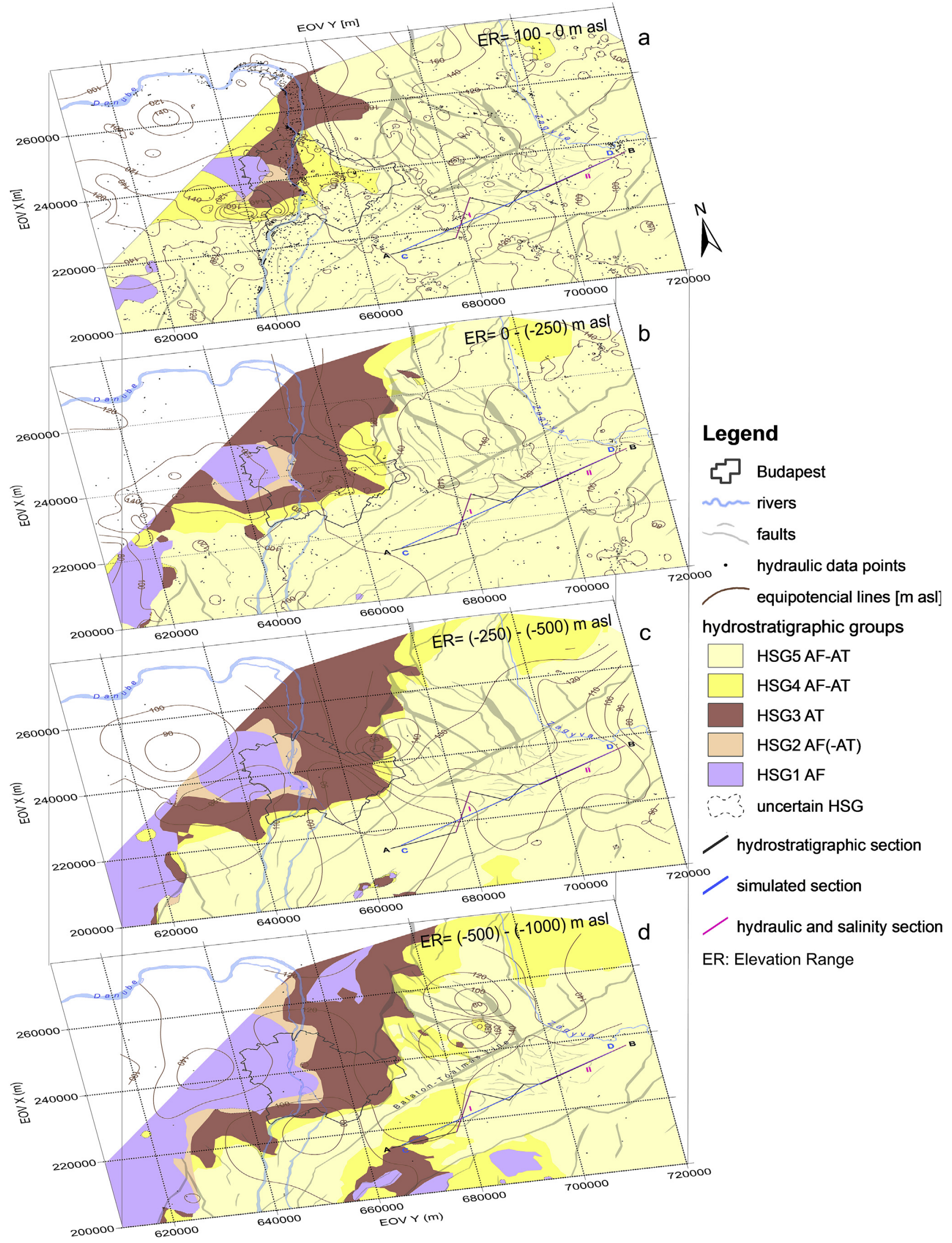

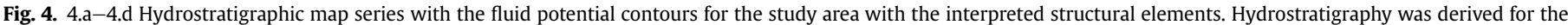

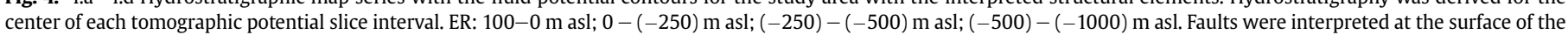
Middle Miocene based on seismic sections by MOL. The hydrostratigraphic maps were derived from Figs. 5.1-5.13 of Mádlné Szőnyi et al. (2013). 


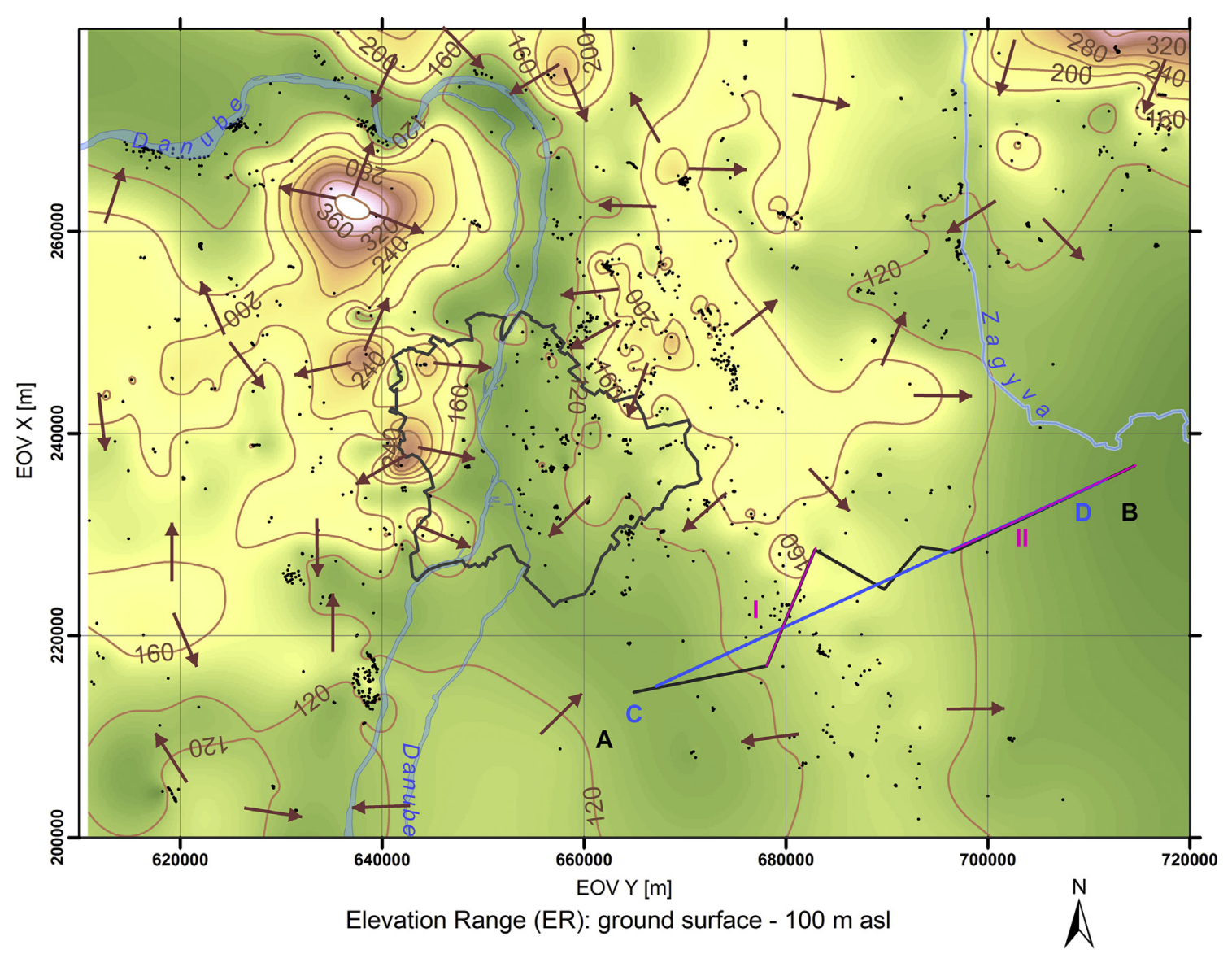

Legend
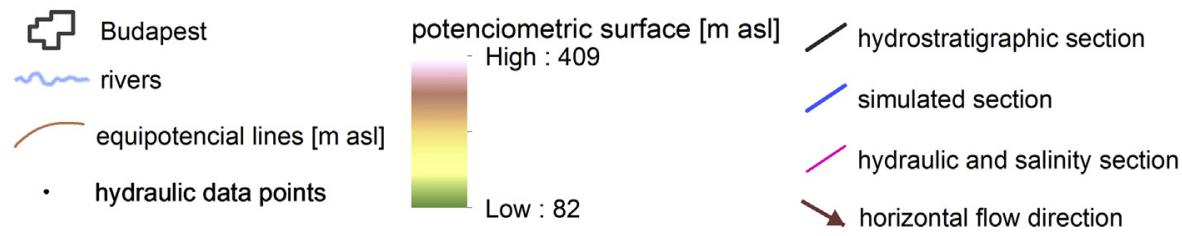

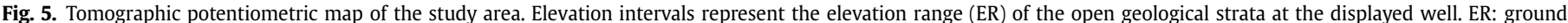
surface-100 $\mathrm{m}$ asl. Fluid potential values are indicated by colours and lines.

for $(-500)-(-1000) \mathrm{m}$ asl (Fig. 4d) whereas these groups also appear to in the south of the Balaton-Tóalmás Line. The HSG3 AT group surrounds the HSG1 and 2 from NE and E close to the surface (Fig. 4a). Its areal extent increases in the south and north-east of Budapest towards the deeper elevations (Fig. 4b-d). In the deepest slice it appears to the south of the Balaton-Tóalmás Line as well (Fig. 4d). HSG4 AF-AT can be seen only in the surroundings of Budapest on the upper hydrostratigraphic map (Fig. 4a). The increase in its areal extent can be followed in the deeper slices, particularly in the northern part of the study area as well as to the south of the Balaton-Tóalmás Line (Fig. 4d).

The hydrostratigraphic section (Fig. 3) shows the vertical distribution of hydrostratigraphic units and the structural elements in the south of Balaton-Tóalmás Line for the confined part of the study area. We can follow how the position of the top of HSG1 AF and HSG2 AF(-AT) varies from (-1000) $\mathrm{m}$ asl to (-3000) $\mathrm{m}$ asl. It is also characteristic that the thickness of HSG3 AT reaches $1000 \mathrm{~m}$ in the west, but in some parts of the section it is missing or very thin (9-11, 44, 55-57, 58-62 section km). The HSG4 AF-AT appears only east to the 15th section $\mathrm{km}$. Its thickness is the greatest $(\sim 1000 \mathrm{~m})$ between $18-28$ section $\mathrm{km}$. The HSG5 AF-AT covers the hydrostratigraphic units everywhere to a thickness of 800-1800 m.

\subsection{Characterization of the regional flow field on potentiometric maps}

A characterization of the fluid potential (hydraulic head) distribution for the whole study area was required to be able to follow its pattern continuously over different elevation intervals. A tomographic potentiometric map series was compiled for four subsequent elevation intervals with the joint representation of hydrostratigraphy and structural elements (Fig. 4a-d), and for four intervals without hydrostratigraphy (Fig. 6a-d). The upper potentiometric slice (ground surface - $100 \mathrm{~m}$ asl) (Fig. 5) was displayed without hydrostratigraphic categories. The location of the hydraulic datapoints (wells) used for the compilation of each map was indicated for each potentiometric slice.

The data for the deepest potentiometric slice (under $-1000 \mathrm{~m}$ asl) are displayed separately in Fig. 7 a,b. There were not enough available data to represent hydrostratigraphy groups continuously, therefore the hydrostratigraphic category of the source formation is indicated pointwise at each well. Two versions of this map were 


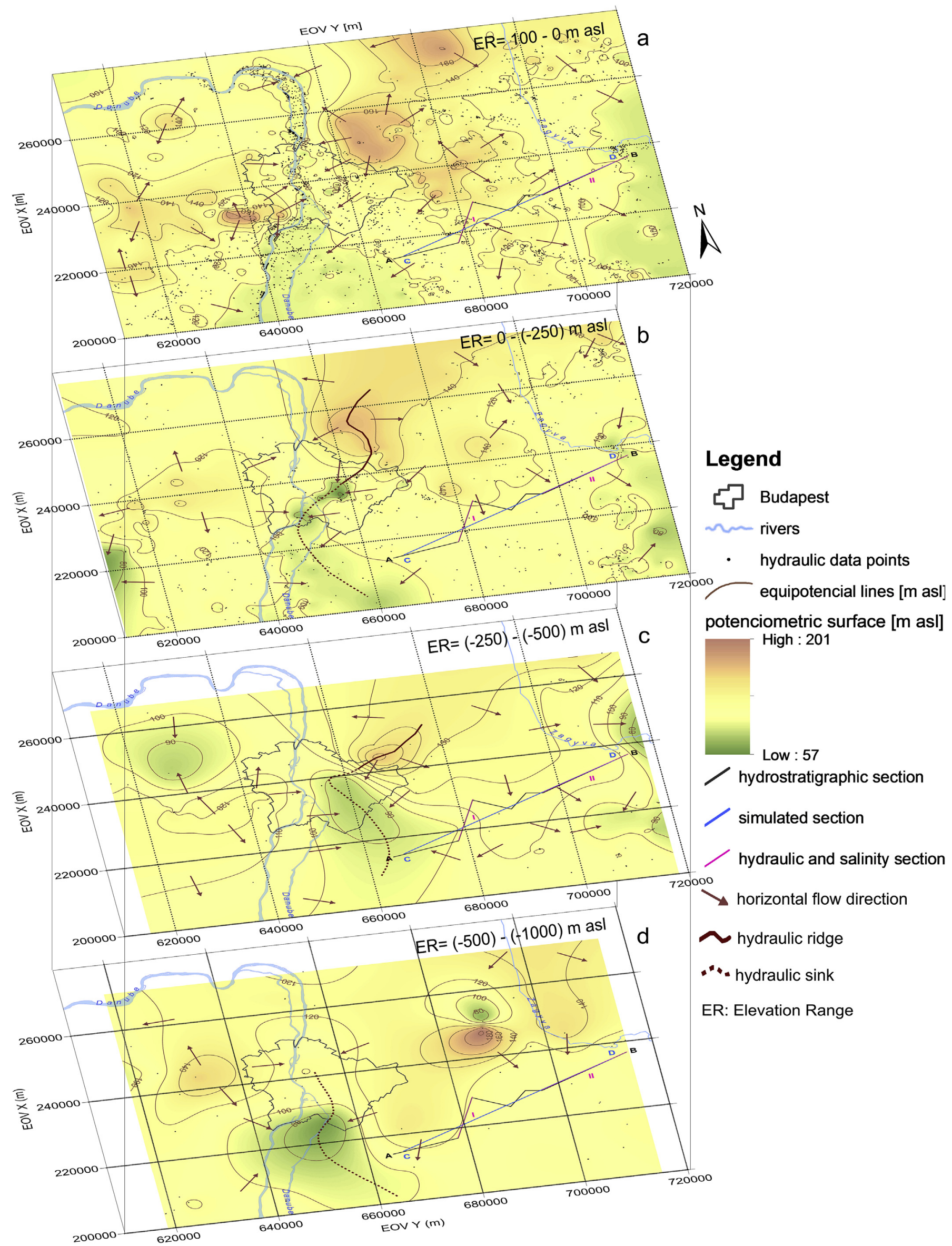

Fig. 6. a-d Tomographic poteniometric map series for the study area. Elevation intervals representing the elevation range (ER) of the opened geological strata by the displayed well. ER: $100-0 \mathrm{~m}$ asl; $0-(-250) \mathrm{m}$ asl; $(-250)-(-500) \mathrm{m}$ asl; $(-500)-(-1000) \mathrm{m}$ asl. Fluid potential values are indicated by colours and lines. 


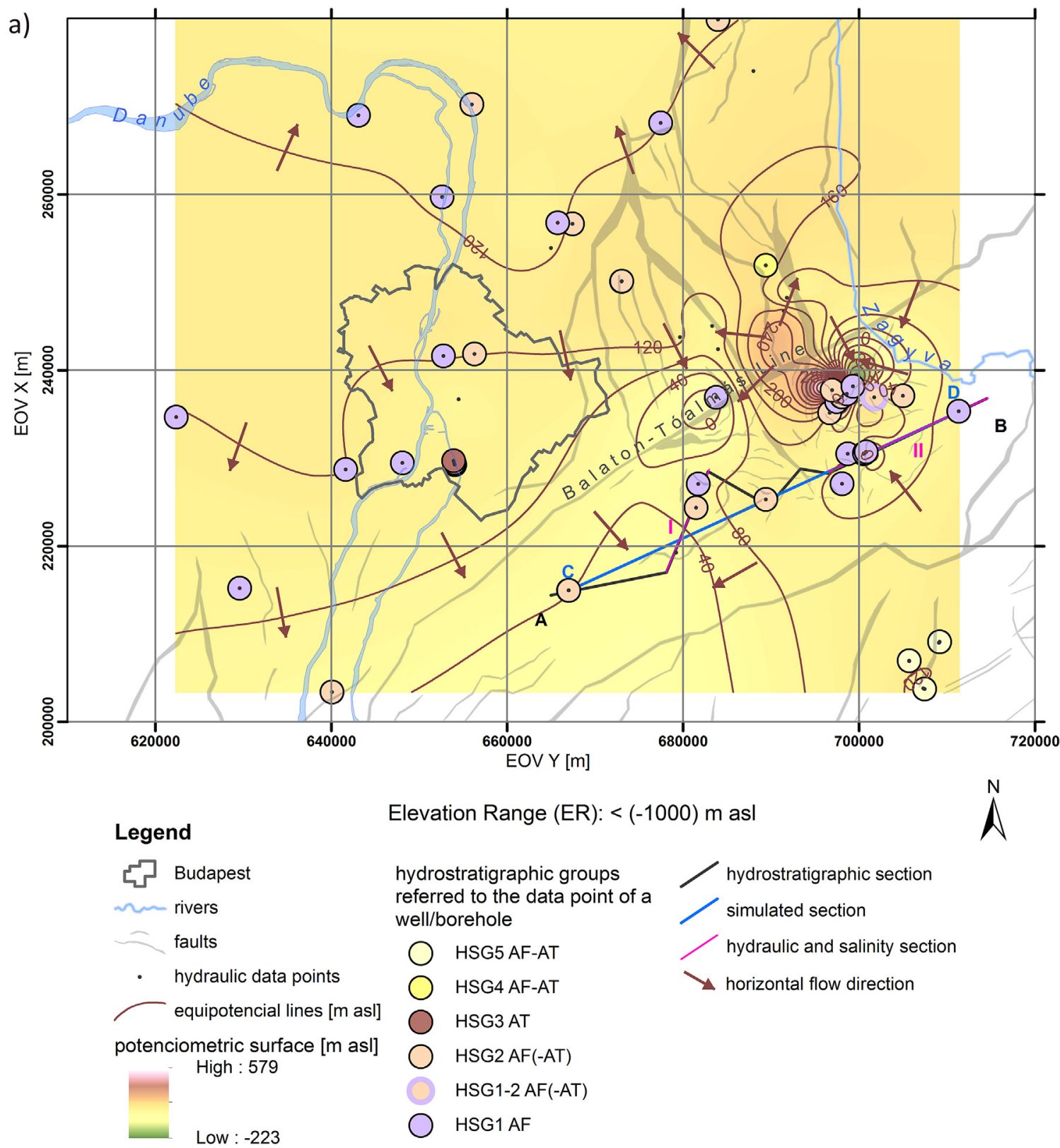

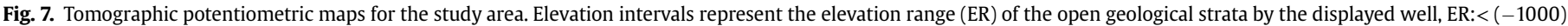

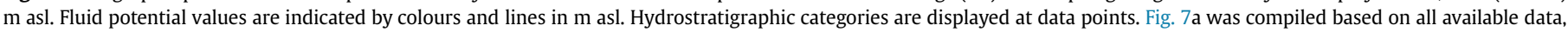
Fig. 7b on data from HSG1 AF and HSG2 AF(-AT).

compiled, one for all available data under $-1000 \mathrm{~m}$ asl (Fig. 7a); the other for only those data representing the basement carbonate hydrostratigraphic units (HSG1 AF and HSG2 AF(-AT)) respectively (Fig. 7b).

The uppermost potentiometric map (Fig. 5) reveals a strong correlation with the surface topography (Fig. 1c). That is the highest $\mathrm{h}$ values can be found in the highlands such as the Pilis ( $360 \mathrm{~m}$ asl), the Buda Hills ( $280 \mathrm{~m}$ asl), the Gödöllo" Hills ( $240 \mathrm{~m}$ asl), and the North-Hungarian Mountain Range ( $320 \mathrm{~m}$ asl). On the other hand, in the low lying central and southern part of the study area the $120 \mathrm{~m}$ asl equipotential shows an elongated asymmetrical closed depression around the Danube, whereas to the east of the Gödöllo" Hills, a fluid potential minimum of $<120 \mathrm{~m}$ asl also occurs.

The next map (Fig. 6a) also represents a correlation with the surface topography. However, compared to the previous map significant hydraulic head decrease can be observed in the highlands, i.e. in the Pilis $(-240 \mathrm{~m})$, the North-Hungarian Mountain Range $(-180 \mathrm{~m})$, the Buda Hills $(-150 \mathrm{~m})$, and the Gödöllo" Hills $(-80 \mathrm{~m})$. The only remarkable exception is the area of the Tétény Plateau to the SW of Budapest (Fig. 1c) where hydraulic heads show slight increases $(+20 \mathrm{~m})$ thus forming a positive WNW-SSE oriented potentiometric mound in relation to its surroundings. In the lowlands the position of equipotentials does not display noticeable changes. Comparing the potentiometric surface with the relevant hydrostratigraphy (Fig. 4a) a strong correlation does not appear. The only observable feature is that the potential mounds connected to the topography can be subsumed in the siliciclastic cover, namely in the HSG4 AF-AT (in the Tétény Plateau) and in the HSG5 AF-AT 

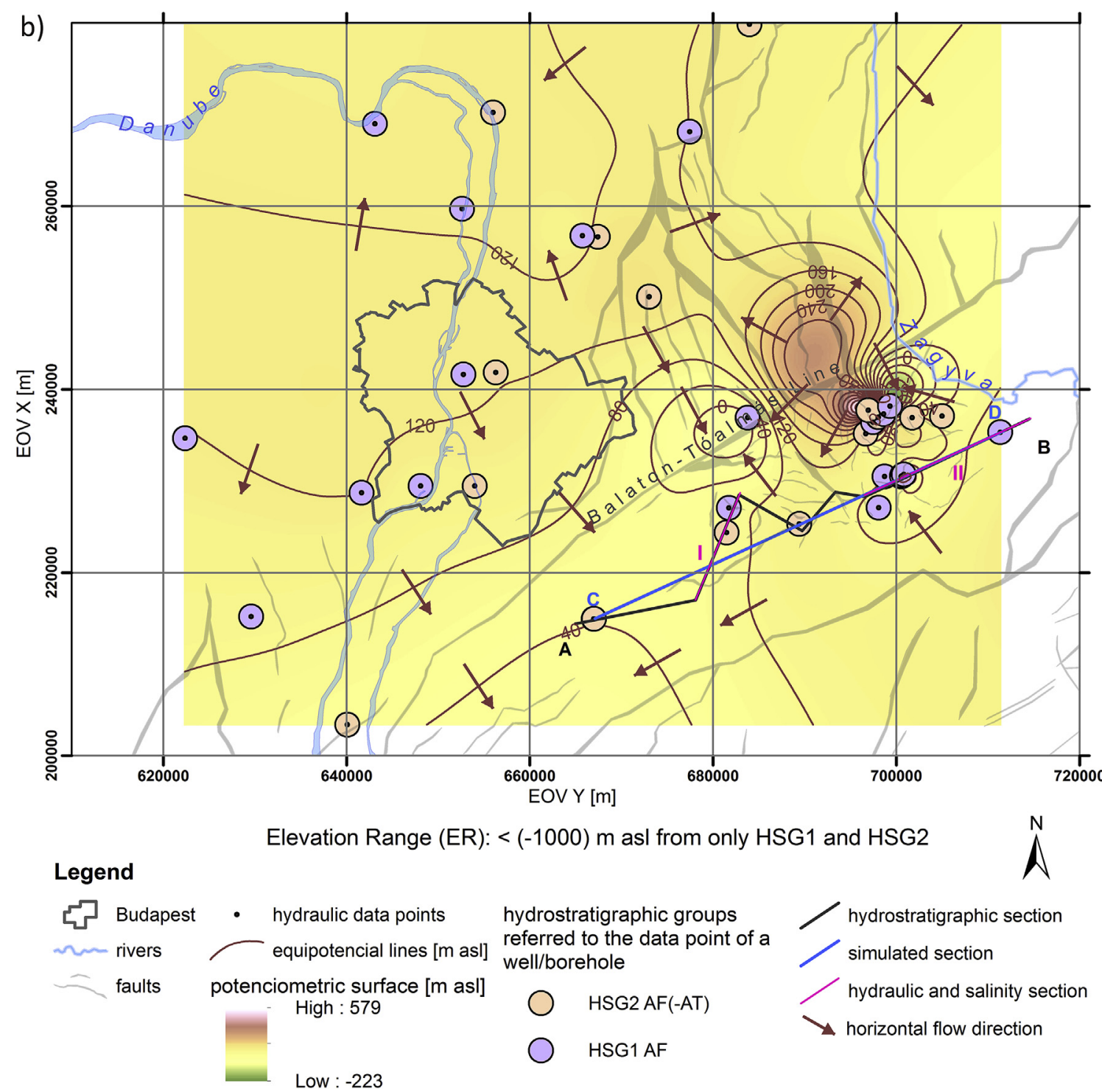

Fig. 7. (continued).

(in the Gödöllső Hills and North-Hungarian Montain Range).

In the further potentiometric slice (Fig. 6b) there are fewer data, therefore the potentiometric picture is more schematic. The potentiometric mounds in the Gödöllö Hills ( $160 \mathrm{~m}$ asl) and to the west of Budapest ( $120 \mathrm{~m}$ asl) still exist but within restricted areas. An interesting feature is the shrinking of the potentiometric depression characterized by less than $100 \mathrm{~m}$ asl hydraulic head values and its SW-NE orientation in the area of Budapest. In its center equipotentials of less than $80 \mathrm{~m}$ asl can be found. These values can not be correlated with the recent topography, but with the extent of HSG3 AT (Fig. 4b). The flow in this low hydraulic conductivity unit (HSG3 AT) is restricted from the NNE thus elevated hydraulic gradients are generated, particularly the Gödöllö Hills $\left(\right.$ gradh $\left._{\mathrm{h}}=5 \mathrm{~m} / 1000 \mathrm{~m}\right)$.

The next map (Fig. 6c) is the deepest on which any correlation with the topography can be observed. Compared to the previous slice, the potentiometric mounds in the Gödöllö Hills (160 m asl) and to the west of Budapest ( $120 \mathrm{~m}$ asl) are limited to even smaller areas, whereas potentiometric depressions evolved in the NW and $\mathrm{SE}$ of Budapest. In common with the previous maps the hydrostratigraphy (Fig. 4c) has no significant effect on the flow field.

The next deeper potentiometric slice (Fig. 6d) differs significantly from the previous ones, though the data availability is worse, therefore the uncertainty is larger in this case. An east-west oriented equipotential of $120 \mathrm{~m}$ asl runs across the study area and forms a potentiometric bay around Budapest. In the center of this depression, hydraulic heads of less than $80 \mathrm{~m}$ asl, are to be found, that is, hydraulic heads lower than the lowest surface topographic elevation. Consequently, this can not be explained by topographically-driven flow. Careful analyses of the original data excluded the effect of production. A similar potential minimum ( $80 \mathrm{~m}$ asl) can be found to the west of the Zagyva River, but with a maximum value $(200 \mathrm{~m}$ asl), it forms a double reverse fluid potential anomaly. In addition, we can see positive anomalies (140 m asl) in the east of the Zagyva and in the western part of the study area. These values do not follow the previous trends and cannot be explained by the effects of topography-driven flow. With regard to the hydrostratigraphic map (Fig. 4d), no direct correlation with the potential distribution can be seen. Only the faults, and particularly 
the Balaton-Tóalmás Line may have had an influence on the regional fluid potential field since the anomalies evolved in their surroundings.

The data for the deepest potentiometric slice (under $(-1000) \mathrm{m}$ asl) can be seen in Fig. 7a., which shows considerable change in the potential field. In the northern, north-western and southeasternmost parts of the study area the potential values are close to $120 \mathrm{~m}$ asl. However, hydraulic heads are generally low (around $40 \mathrm{~m}$ asl) in the central and eastern parts, and particularly south of the Balaton-Tóalmás Line. Furthermore, we can see fluid potential anomaly ( $0 \mathrm{~m}$ asl) along the Line, and a double reverse potential anomaly (positive $>300 \mathrm{~m}$ asl, and negative, $<0 \mathrm{~m}$ asl next to each other) south of it. Though the fluid potential decreasing effect of hydrocarbon production cannot be excluded, the distribution of data implies rather a regional effect due to this significant tectonic element, as also to crosscutting faults as well.

One of the main questions of the study was how deep carbonate aquifers (HSG1 AF and HSG2 AF(-AT)) are connected to their unconfined equivalents and their confining layers. With the aim of a better understanding of the lateral hydraulic connections with the unconfined western region, a tomographic potentiometric map was compiled using only the data of HSG1 AF and HSG2 AF(-AT) with measurement point elevation $<-1000 \mathrm{~m}$ asl (Fig. $7 \mathrm{~b}$ ). On a regional scale, the fluid potential field does not show any significant difference compared to that to be seen in Fig. 7a. However, this map shows the lateral connections between the unconfined and confined regions. The horizontal hydraulic gradient can be estimated between the 120 and $80 \mathrm{~m}$ asl equipotentials in the area of Budapest towards the Balaton-Tóalmás Line $\left(\operatorname{gradh}_{\mathrm{h}}=2.35 \mathrm{~m} /\right.$ $1000 \mathrm{~m}$ ). This potential drop continues to the south of the Line as well. In addition, the positive and negative fluid potential anomalies appear on this map.

\subsection{Regional salinity distribution}

Salinity distribution was evaluated based on the TDS content of water and categorized as follows: fresh $<1000 \mathrm{mg} / \mathrm{l}$; brackish: 1000-10,000 mg/l; saline: $10,000-100,000 \mathrm{mg} / \mathrm{l}$, the groups being indicated in blue, yellow and red respectively on the maps (Fig. $8 \mathrm{a}-\mathrm{d}$ ). To be better able to follow the salinity changes, the brackish category was divided into two subcategories (1000-2000 and $2000-10,000 \mathrm{mg} / \mathrm{l}$ ) and the saline category into five subcategories (10,000-20,000; 20,000-30,000; 30,000-40,000; $>40,000 \mathrm{mg} / \mathrm{l})$. The salinity maps were compiled for the same elevation intervals as the potentiometric and hydrostratigraphic map series to compare these parameters in the course of the interpretation. On the salinity maps the structural pattern was also displayed. For the upper slice (ground surface $-100 \mathrm{~m}$ asl) there were no available data in the database which could be used for salinity evaluation. For the next two slices only individual data points were displayed with a salinity category. The locations of the salinity datapoints (wells) used for the compilation of each of the maps were indicated for every salinity slice. The salinity distribution was consequently compared with hydrostratigraphy and the structural pattern during the description. The data for the deepest slice $\mathrm{ER}<-1000 \mathrm{~m}$ asl were displayed separately, as with the tomographic potentiometric maps and together with the display of individual hydrostratigraphic categories of the wells. This map was also compiled in two versions, for all available data under $-1000 \mathrm{~m}$ asl (Fig. 9a), and for only those which lie open to the basement carbonate hydrostratigraphic units (HSG1 AF and HSG2 AF(-AT)) (Fig. 9b).

Before presenting the results, it is worth recalling the characteristic type of pore water (i.e. saline, brackish or fresh) for each hydrostratigraphic unit (Table 1 ). To reiterate, the basement carbonates contained originally saline water, though meteoric infiltration influenced them during the terrestrial period after the Late Cretaceous. The Eocene-Oligocene siliciclastic carbonate units of HSG2 AF(-AT) originally also contained saline water but they were influenced by meteoric infiltration during the Late Oligocene. From the Early Miocene the HSG4 AF-AT contained saline water, but from the Middle Miocene brackish and meteoric water also existed in the upper part of the system.

For the first tomographic slice (100-0 m asl) (Fig. 8a) very few data were available and only one saline datum can be found in the eastern part of the study area. The data do not show a direct correlation with the hydrostratigraphy (Fig. 4a), but rather with the tomographic fluid potential map (Fig. 6a). The western, higher fluid potential part of the study area is represented by fresh water, while the low potential area, at the Danube, is characterized by brackish water.

Similar trends appear in the next slice $0-(-250) \mathrm{m}$ asl (Fig. 8b), but these are based on less dense data. However, north-east of Budapest all of the three salinity categories appear, without visible pattern. Here we can find more saline and brackish samples, which may well be connected to be the hydrostratigraphy represented by HSG3 AT and HSG4 AF-AT (Fig. 4b). It may also be the case that they are due to the dominant brackish and saline character of pore water in this area. By way of contrast, the tomographic potential map indicates a potential mound ( $160 \mathrm{~m}$ asl) for this region, indicating a recharge position in the fluid potential field (Fig. 6b). This effect may be influenced by the use of a single fresh water datum.

The first salinity contour map was compiled for the slice of $(-250)-(-500) \mathrm{m}$ asl (Fig. 8c). Here a very special salinity pattern may be seen which correlates well with the fluid potential distribution (Fig. 6c) and hydrostratigraphy (Fig. 4c). In the north-eastern part of Budapest we can find a saline water body of $10,000-20,000 \mathrm{mg} / \mathrm{l}$ TDS around the fluid potential minimum within the HSG3 AT, surrounded by brackish and fresh water, particularly of the HSG1 AF, HSG2 AF(-AT) and HSG5 AF-AT units. The existence of fresh water correlates very well with potentiometric mounds in the NE and SW of Budapest. The widespread fresh water in the eastern part of the study area can be found within the HSG5 AF-AT, but its areal extent is equivocal due to the lack of data for its central part.

In the next slice $((-500)-(-1000) \mathrm{m}$ asl) (Fig. 8d) significant changes in salinity distribution may be observed compared to the previous map. The center of the saline water zone is shifted to the eastern part of the study area and shows higher concentrations (>40,000 mg/l) as well. Also, the greater extent of HSG4 AF-AT in this slice (Fig. 4d) may be responsible for the higher salinity in this region. The highest TDS values can be found along the BalatonTóalmás Line where the influence of the fluid potential anomalies (Fig. 6d) can be seen as well, where saline waters can be found around the positive anomalies of upward flow, and brackish or even fresh waters around the negative fluid potential anomalies of downward flow. Fresh water appears at the northern and eastern edges of the map and in greater areal extent in the west-northwest of Budapest, where it shows a strong correlation with the areal expanse of HSG1 AF (Fig. 4d).

The salinity maps show significant differences for the deepest slice ER $<(-1000) \mathrm{m}$ asl if we compile them for all water samples (Fig. 9a) or only for those originating from HSG1 AF and HSG2 AF(AT) (Fig. 9b). The latter shows a large area of fresh water on the western side of the area with a limb across the Danube in northern Pest. This fresh water is surrounded by brackish water to the east and south. The appearance of saline water correlates closely with the Balaton-Tóalmás Line, while the highest salinity values can be found south of it. In contrast to this clear salinity distribution, the map compiled for all available data (Fig. 9a) reflects the salinity of 


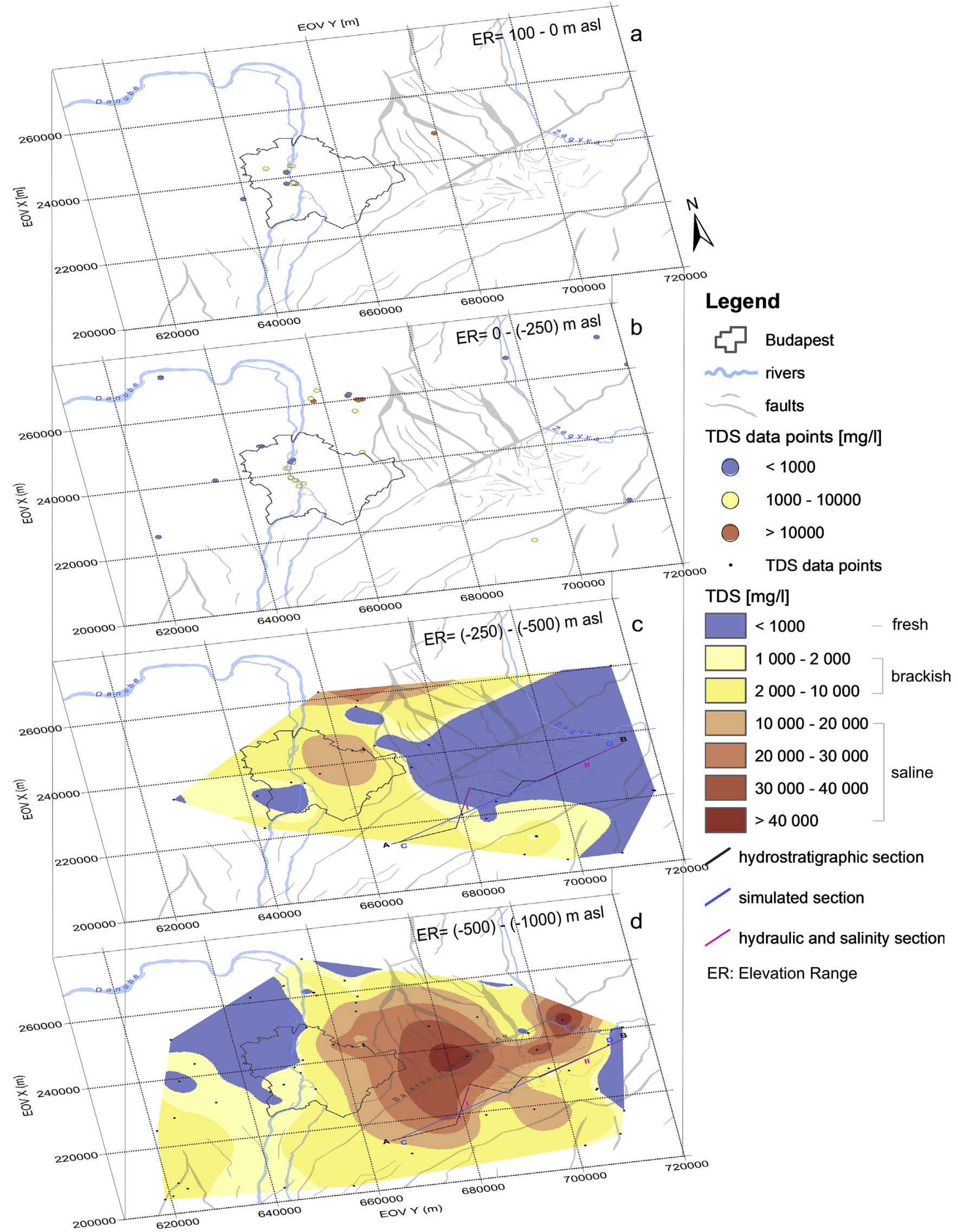


the carbonate basement and also the different confining formations under $(-1000) \mathrm{m}$ asl elevation. From the western part of the study area there are only two additional data but interpolation shows a greater influence of brackish water originating from the covering formations. The high salinity zone east of the Danube appears to be distributed in a wider area and of greater extent compared to the slice of $(-500)-(-1000) \mathrm{m}$ asl (Fig. 8d). In addition, the effect of potential anomalies (Fig. 7a) appears in the form of salinity anomalies as well. The negative potential anomaly of $0 \mathrm{~m}$ asl is surrounded by brackish water north of the Balaton-Tóalmás Line is sharply distinguished from the double reverse anomaly, as they are characterized by higher and lower salinity, respectively (Figs. 9a and $7 \mathrm{a})$.

\subsection{Evaluation of hydraulic and salinity data along a hydrostratigraphic section}

In order to evaluate the characteristic flow pattern and vertical interactions between basement carbonates and confining formations hydraulic cross sections were compiled (Fig. 10) for two parts (I and II) of the hydrostratigraphic section (Fig. 3). The sections contain well/borehole data along the sections and additional data were projected onto them from up to $1 \mathrm{~km}$ away. The interpretation of the inserted data is more uncertain and their hydrostratigraphy does not match that of the sections in some cases due to local heterogeneities. Furthermore, the equipotentials from the tomographic potential maps were also added to the sections in order to fill in the blank spaces of missing data. The section displays fluid potential values from the surface down to $-1000 \mathrm{~m}$ asl elevation, because on the basis of tomographic potential maps, it was found that gravity influences the flow in the near surface region. In contrast, the deeper fluid potential values represent other flow driving force(s) and fluid potential anomalies. To reveal these phenomena along the section, pressure deviations from the nominal hydrostatic values in percentage were shown. Salinity was also represented by the measured TDS values in $\mathrm{mg} / \mathrm{l}$.

Surface topography along section I (Fig. 10) increases from the western edge (SSW) (water level $\sim 130 \mathrm{~m}$ asl) towards the ridge of the Gödöllő Hills (NNE) (water level $\sim 160 \mathrm{~m}$ asl) (Fig. 5). This generates a significant downward flow along the section, whereas below the ridge a lateral flow component also appears. Below about $(-500) \mathrm{m}$ asl negative pressure deviations (i.e. subhydrostatic pressures) could be observed all along the section. The rate of the deviation seems to be determined by the thickness of the HSG3 AT, in as much as the thicker the HSG3 AT, the greater the negative pressure deviation within and below it. The water in the HSG5 AFAT is brackish, while in the deeper units it is saline with higher salinity values in the deeper part of the basin (under the ridge of the Gödöllö Hills in the NNE part of the section).

Section II (Fig. 10) is located in the eastern foreland of the Gödöllö Hills and has a lower topographic elevation compared to section I (water level in the $\mathrm{SW}>120 \mathrm{~m}$ asl; $\mathrm{NE}<90 \mathrm{~m}$ asl). At shallower depths in accordance with the surface topography and water table configuration, a less pronounced downward but more intense lateral flow in the SW and central part may be observed, and an upward flow may be supposed towards the Zagyva River, at the NE termination of the section. However, taking into consideration the $110 \mathrm{~m}$ asl equipotential indicated by the dashed line, projected onto it from the tomographic potential map, a downward water movement and hydraulic communication between the covering strata and underlying aquifers also lying below the nearsurface discharge zone may be interpreted. Also along this section below about $-1000 \mathrm{~m}$ asl negative pressure deviations (i.e. subhydrostatic pressures) occur with a magnitude apparently related to the thickness of the HSG3 AT. That is in the HSG1 AF negative pressure deviations are smaller where HSG3 AT is thinner, particularly in the basement highs (at 1500 and 16,000 section $\mathrm{m}$ ). The water in the HSG5 AF-AT is brackish, while in the deeper units it is saline with a brackish exception at 16,500 section $\mathrm{m}$, where pressure deviation is minimal as well. Comparing the two sections (I and II) we can see bigger pressure deviations under the hilly region (section I).

\subsection{Numerical validation of the flow pattern for the deep confined area along a section}

The two sections (I and II) (Fig. 10) do not contain sufficient measured data to reveal fully the potential vertical connections between the deep confined carbonate hydrostratigraphic units (HSG1 AF and HSG2 AF(-AT)) and their confining strata (HSG3 AT and HSG4 AF-AT). However, the results of comprehensive data analysis may be augmented by numerical simulation that could assist to reveal the flow pattern and hydraulic connections.

Along the line of the hydrostratigraphic section (A-B) (Fig. 3), a simplified section (C-D) was designated for 2D numerical flow and heat transport simulations. The influencing effect of heat could not be excluded due to the high temperature $\left(\sim 160^{\circ} \mathrm{C}\right)$ in the basement carbonate (HSG1 AF). The simulated section is almost parallel with the Balaton-Tóalmás line and perpendicular to the watershed of the Gödöllö Hills (Figs. 1 and 2). In the numerical validation the goal was the representation of the flow pattern along the section. Besides this, we also tried to understand the modifying effect of underpressure which is probably at the greatest in the HSG3 AT.

The model domain was derived from the character (geometry, water table, geology-hydrostratigraphy tectonic and structural pattern) of the hydrostratigraphic section (Fig. 3) and from the fluid potential field (Figs. 5 and 6). However, the actual situation was used only as an analogue for the determination of the main characteristics. Consequently, a simplified 2D section was derived with the main stratigraphical features complemented by only a few tectonic elements, basement highs etc. (Fig. 11a).

The length of the numerically simulated domain is $48,500 \mathrm{~m}$. The depth of the basin (measured from $0 \mathrm{~m}$ asl) is $3500 \mathrm{~m}$, which is the thickness of the sequence. The water table was considered the upper boundary of the flow domain. Its elevation was defined as $\mathrm{z}_{(\mathrm{x}=0 \mathrm{~m})}=100 \mathrm{~m}$ asl; $\mathrm{z}_{(\mathrm{x}=20,000 \mathrm{~m})}=125 \mathrm{~m}$ asl; $\mathrm{z}_{(\mathrm{x}=48,500 \mathrm{~m})}=90 \mathrm{~m}$ asl with continuous, straight descending and ascending parts. At the lateral boundaries fixed heads were applied, on the left-hand side at $100 \mathrm{~m}$, and on the right-hand side at $90 \mathrm{~m}$. The lower boundary was of the no-flow type. The applied effective porosity in \% and horizontal hydraulic conductivity ( $K$ values in $\mathrm{ms}^{-1}$ ) are indicated in the simulated section domain (Fig. 11a). The vertical $K$ values were chosen at one order of magnitude less than the horizontal, the faults were implemented with a value of $K=10^{-5} \mathrm{~ms}^{-1}$. The heat conductivity values were determined only for carbonate and dominantly siliciclastic hydrostratigraphic units, and were shown in $\mathrm{Wm}^{-1} \mathrm{~K}^{-1}$ in the section (Fig. 11a). The temperature along the base of the section was chosen as $162{ }^{\circ} \mathrm{C}$, and the surface temperature was initially defined as $11^{\circ} \mathrm{C}$, in agreement with the average surface temperature and the characteristic geothermal gradient of

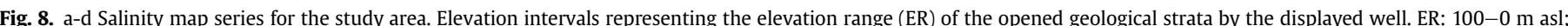

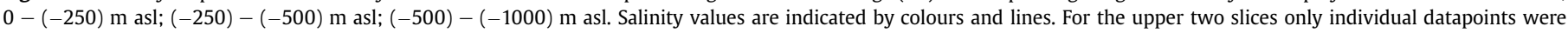
displayed with salinity category. The faults were interpreted for the surface of Middle Miocene based on seismic sections by MOL Plc. 


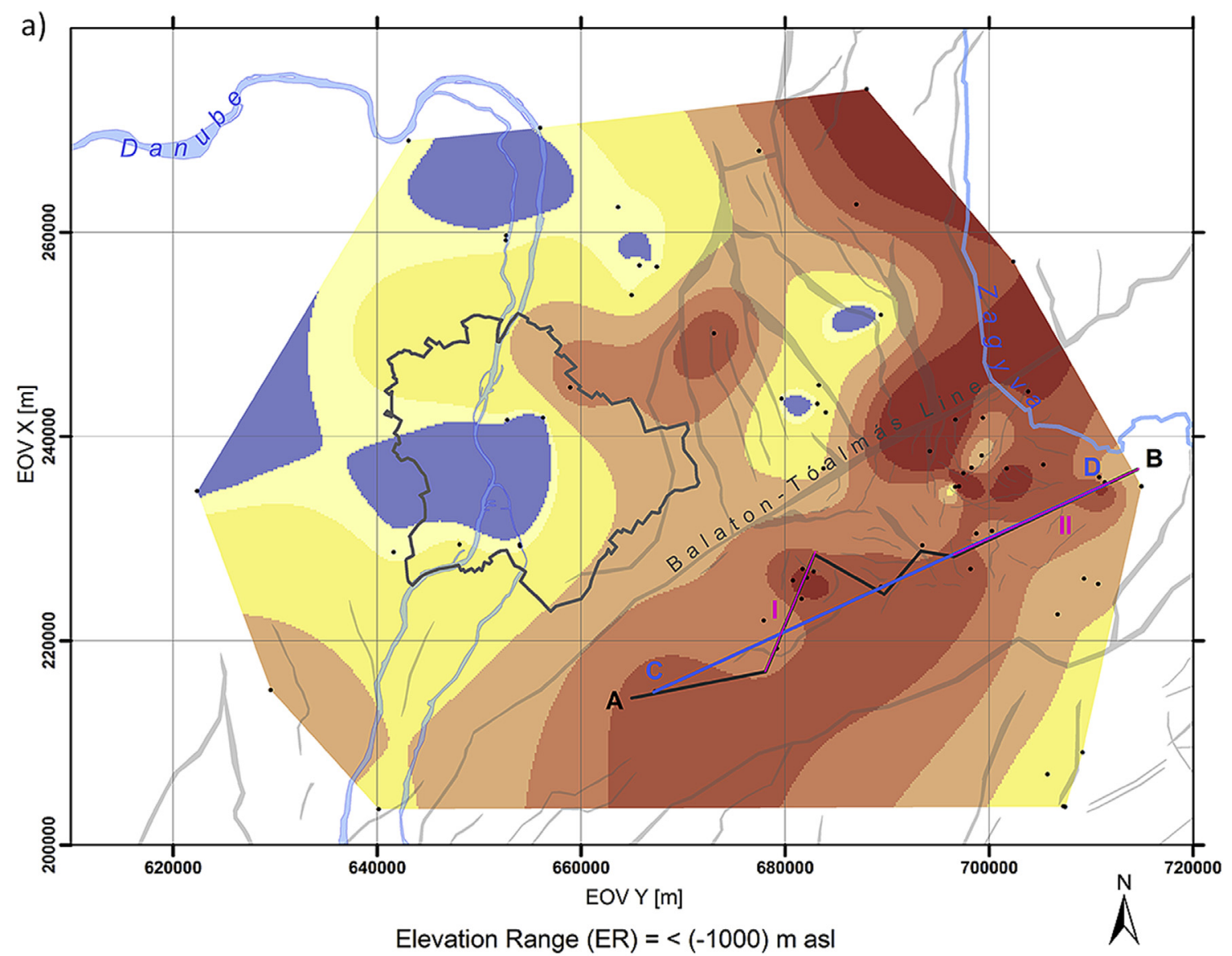

Legend
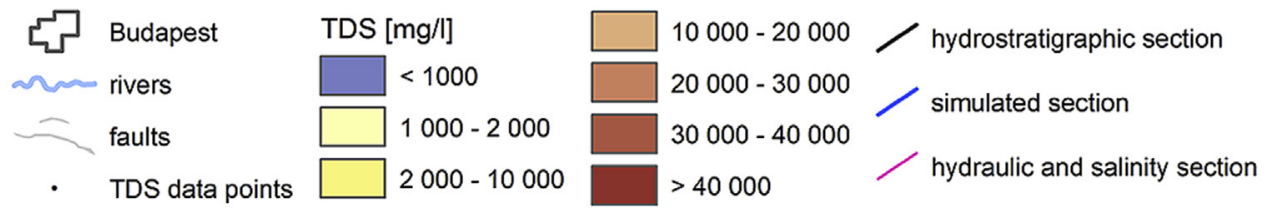

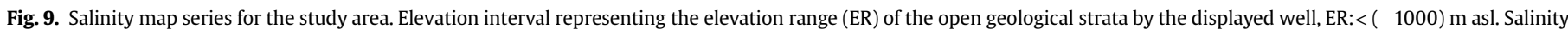

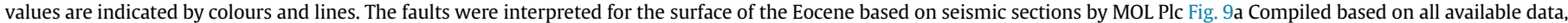
Fig. 9b based on data from HSG1 AF and HSG2 AF(-AT).

$4.2^{\circ} \mathrm{C} / 100 \mathrm{~m}$. Temperature values at the lateral boundaries were defined based on the geothermal gradient.

In the course of the data analysis a very significant feature which was revealed, was the underpressure indicated by negative pressure deviations (Fig. 10). The underpressure is more significant along section I, and it is more pronounced in the HSG3 AT. Toward the NE edge of the section the underpressure ceases to be present. To implement this significant effect into the simulation, the initial pressure was decreased in the HSG3 AT group compared to hydrostatic pressure by $3 \%$ and $2 \%$, in the central and eastern parts of the section respectively (Fig. 11a.). These deviations are less than those seen based on measured values in Fig. 10.

The flow pattern can be seen without the consideration of the effects of heat in Fig. 11b. The Darcy's velocity vectors are displayed in normalized form based on flow simulations. The elevated water table at the ridge (around 20,000 section $\mathrm{m}$ ) represents a recharge area for groundwater characterized by a downward vertical flow component. Towards the edges of the section predominantly horizontal flow can be observed. In deeper segments of the section, under $-1000 \mathrm{~m}$ asl vertical flow can be observed almost everywhere. In the surroundings of the basement high, determined by faults we can observe tectonically and hydraulically fostered vertical downward communication. The role of faults in orienting downward flow can be observed at 15,000, 20,000 and 27,000 section $\mathrm{m}$. The effect of underpressure on the flow field in HSG3 AT very extensively influences the pressure conditions in the basement carbonate aquifers (HSG1 AF and HSG2 AF(-AT)) also. We can see the development of even lower pressures (hydraulic heads in the center of the section $\sim 40-50 \mathrm{~m}$ asl). This has led to the development of a fluid potential sink in the deep aquifer drawing all water into its center.

The flow pattern was also derived taking into account the effect of heat (Fig. 11c). The Darcy's velocity vectors were displayed in the form of magnitude control based on flow and heat transport simulations. In this figure intense flow paths appear only in HSG1 AF, due to the differences in fluxes compared to the upper 


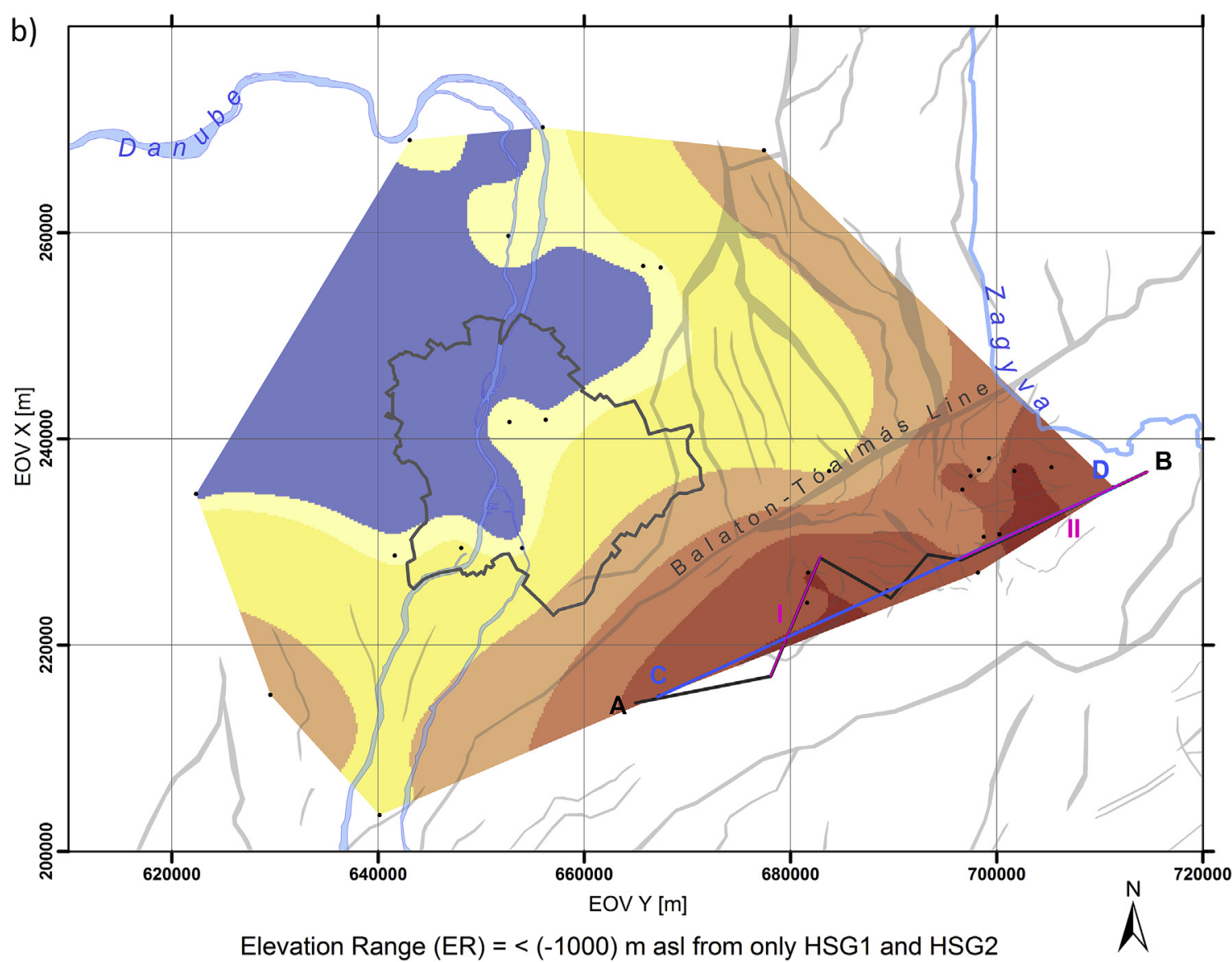

Legend

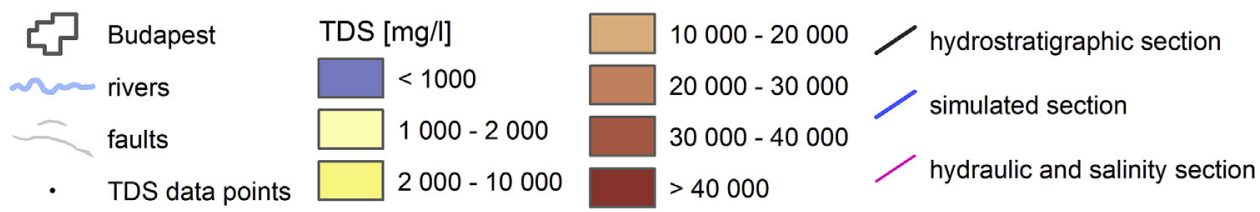

Fig. 9. (continued).

hydrostratigraphic units. We can follow the fluid flow toward the center of the section but its decreasing intensity indicates the effect of the fluid potential sink. The section also shows that the intense flow from HSG1 AF has an upward component at the fault to be found at 14,000 section $\mathrm{m}$. The temperature distribution also shows the effect of those zones where vertical communication can exist between the heat resistant layers.

\section{Interpretation and discussion}

In contrast to the traditional view, a basin-scale analysis provides a systematic approach for the understanding of the fluid potential field (based on measured hydraulic head values) of the area as a whole (including aquifers and aquitards). Consequently, this approach handles the flow field in the confined carbonate system of the study area not as an a priori closed system, but attempts to find posteriori evidence (based on measured data) for its hydraulic condition. The salinity pattern is used in the approach as complementary information for understanding the hydraulic pattern. The applied approach is suitable for the setting up of a so called steady-state snapshot of the fluid potential field. In this snapshot, however, the effects of geologically transient flow are also reflected.

\subsection{Gravity-driven regional groundwater flow (GDRGF) and salinity pattern of the study area}

The systematic fluid potential evaluation of the study area revealed the clear influence of topographically induced gravitydriven regional groundwater flow (GDRGF) systems down to $(-500) \mathrm{m}$ asl elevation, independently of hydrostratigraphic categories (Figs. 5 and $6 a-$ c, Fig. $4 a-c$ ). The Pilis, Buda Hills, Gödöllö Hills and the North-Hungarian Mountain Range appear in the fluid potential map as recharge areas with high fluid potential values (up to $360 \mathrm{~m}$ asl) on the shallowest map (Fig. 5), thereafter with decreasing values in the deeper ones (Fig. $6 \mathrm{a}-\mathrm{c}$ ), reflecting downward flow. The only exception is the Tétény Plateau where a new potential mound appears in Fig. 6a. On the other hand, the Pest Plateau, the Zagyva valley and the northern territories of the Great Hungarian Plain represent the discharge areas (all being less than $120 \mathrm{~m}$ asl) of the flow systems. The Danube itself acts as the main discharge area of GDRGF only from the ground surface $0 \mathrm{~m}$ asl 


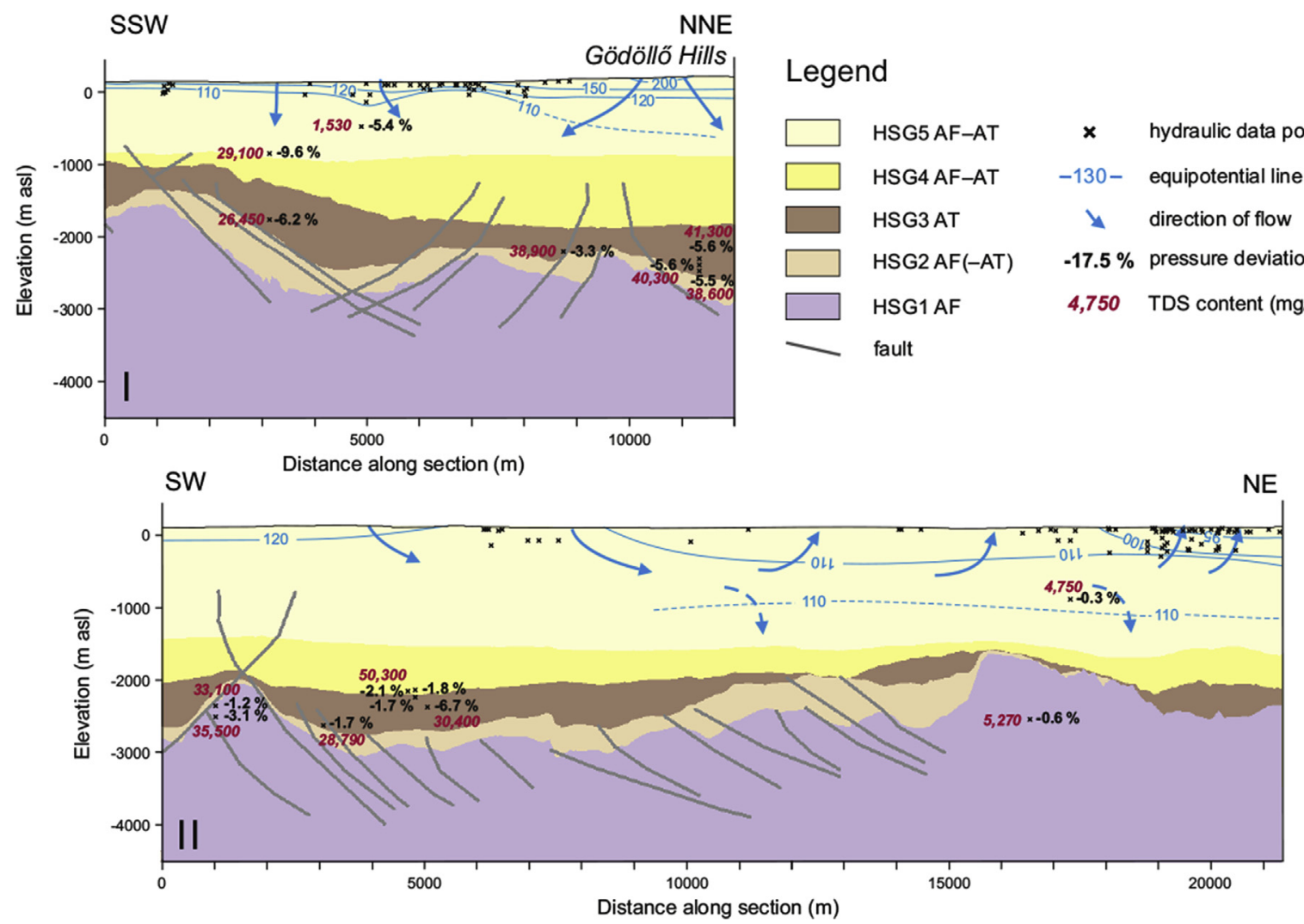

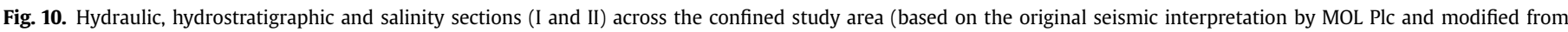

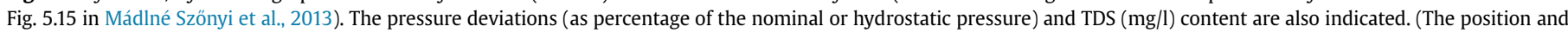
location of the sections can be seen in Figs. 2 and 3).

elevation (Figs. 5 and 6a), whereas the River Zagyva does not discharge in the same slices, since equipotentials run across it and decrease further toward areas with lower topographic elevation.

At the same time, in the map series we can also follow the modifying effect on the fluid potential field of the complex geology and hydrostratigraphy. While on the shallowest map (Fig. 5) the value of highest hydraulic head (in the recharge areas) is directly proportional to the topographical elevation (i.e. the higher topography the higher $h$ value), the rate at which h decreases with depth is different east and west of the Danube. So, higher fluid potentials are retained in the Gödöllö Hills than in the Pilis and Buda Hills (Fig. $6 a-c$ ), which can be explained by the thickening of the confining units, particularly the HSG3 AT, eastwards. It impedes the downward flow of recharging waters towards the carbonate basement. Furthermore, in the central discharge area the lowest potential values change with depth from the Danube to the east (the Pest Plateau) (Figs. 5, 6a-c), where even lower potential values $(80-90 \mathrm{~m}$ asl) may be found (Fig. $6 \mathrm{~b}-\mathrm{c}$ ). The $<88 \mathrm{~m}$ asl fluid potentials cannot be interpreted as the consequence of surface topography (the lowest surface elevation in the area is $88 \mathrm{~m}$ asl) (Fig. 1c). These are thus the first recognized abnormal fluid potential values, indicating a fluid potential sink. One possible explanation for its existence may be the influence of the extensive HSG3 AT which may cause a recharge deficit over geological time scales (it is reflected in abnormally low fluid potential/hydraulic head values). The shifting of this low potential area from the Danube to the east can be explained by the above already mentioned effect of the different hydrostratigraphy of the western (aquifers, HSG1 AF and HSG2 AF-AT predominating) and eastern sides (greater influence of confining aquitards, HSG3 AT, HSG4 AFAT, HSG5 AF-AT) (Fig. $4 \mathrm{~b}-\mathrm{c}$ ). These are responsible for the asymmetric fluid potential field between the two sides, i.e. through-flow under the Danube, due to the more intense recharge from the western carbonate aquifers HSG1 AF and HSG2 AF(-AT).

These findings are also reflected in the salinity pattern. In general, recharge areas may be characterized by lower salinity and the discharge areas by higher water salinity. The distribution of fresh water in the eastern part of the study area reflects intense communication through the rock matrix (across HSG5 AF-AT) driven by GDRGF (Fig. 8c). In addition, the presence of brackish water along the Danube in Fig. $8 \mathrm{a}-\mathrm{b}$ seems to indicate the river's main discharging effect, whereas the fluid potential sink (depression) evolving in the deeper slice in the Pest Plateau is characterized by saline water (Fig. 8c).

\subsection{Fluid potential anomalies and salinity pattern in the regional flow field under (-500) $m$ asl elevation}

Below $-500 \mathrm{~m}$ asl elevation we did not find a direct correlation between the recent topography and the fluid potential field (Figs. 6d and 7). In the western part of the study area a potential mound ( $\mathrm{h}>120 \mathrm{~m}$ asl) appears in Fig. 6d, which can refer to the effect of convection that drives fluid up and down into the adjacent slices above (Fig. 6c) and below (Fig. 7), respectively. The fluid potential $\sin \mathrm{k}(\mathrm{h}<80 \mathrm{~m}$ asl $)$ beneath Budapest is shifted southward in Fig. 6d compared to the previous slice (Fig. 6c). This, however, may also be explained by the distribution of data as well, in as much as there is a lack of data on both maps where the potential minimum zone can be observed. Furthermore, in the eastern part of the study area faults and particularly the Balaton-Tóalmás Line may have a significant effect on the flow field since potential anomalies have evolved in their surroundings supposedly due to erosional 
a

C

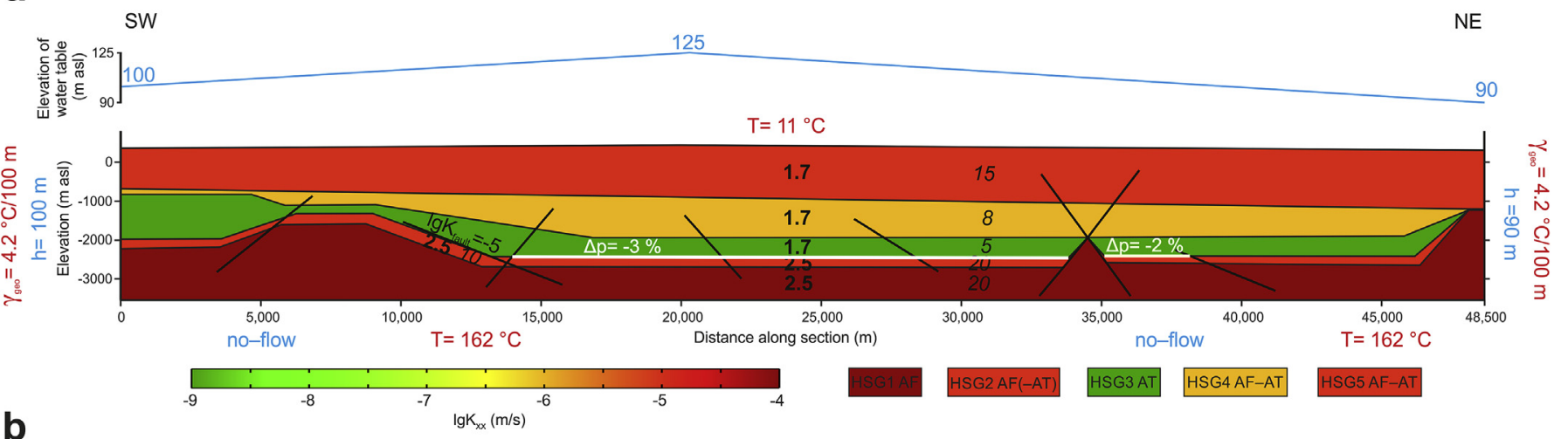

b

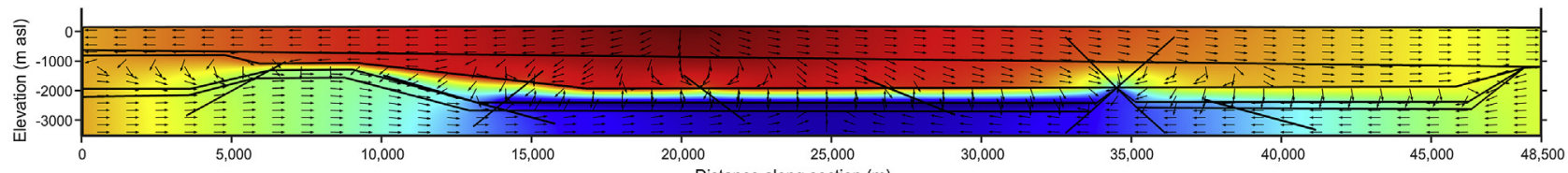

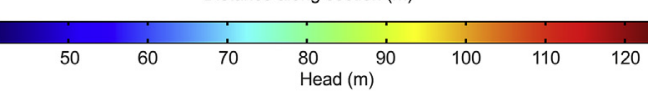

C

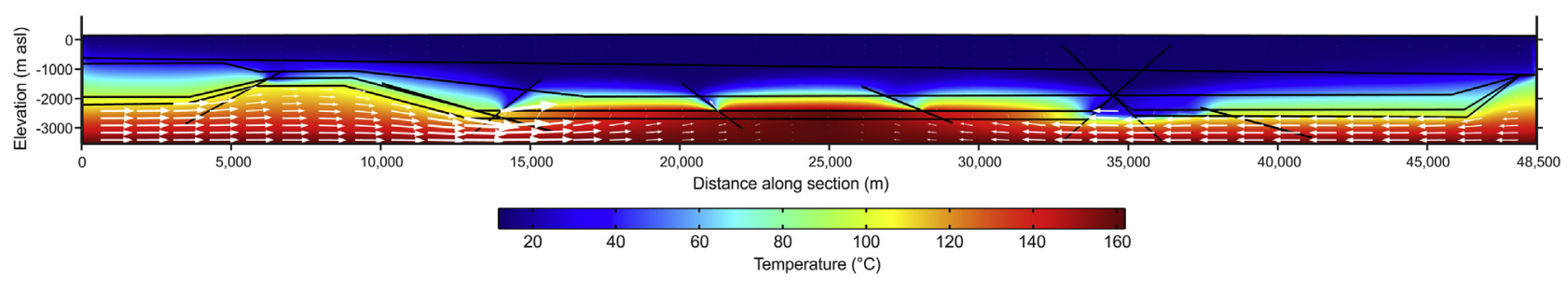

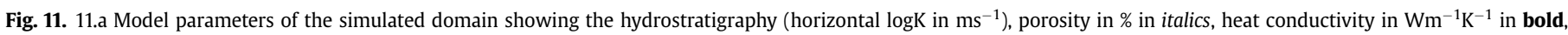
indicated for each hydrostratigraphic unit, complemented by structural elements. Pressure deviations are indicated as a percentage of the hydrostatic pressure. Fig. 11.b Flow distribution, heads (m), streamlines and Darcy's velocity vectors (normalized) based on flow simulations.

Fig. 11.c Temperature distribution $\left({ }^{\circ} \mathrm{C}\right)$, with Darcy's vectors (magnitude control) based on flow and heat transport simulations.

decompaction (Mádl-Szőnyi et al., 2015). This hydraulic picture is in good correlation with the patterns of hydrostratigraphy and salinity (Figs. 4d and 8d). Comparing Fig. 8c and d, we could establish the most significant change in salinity patterns between maps. In the western (basically unconfined) part of the study area the larger fresh water body (Fig. 8d) seems to indicate the influence of the carbonates of HSG1 AF predominates over that of the overlying units. On the other hand, in the eastern (confined) part of the study area salinity increases in waters flowing downward through the siliciclastic confining units, and the more significant contribution of HSG4 AF-AT (Fig. 4d), which originally held marine pore water, can be observed.

Below an elevation of $-1000 \mathrm{~m}$ asl the pattern of water movement is directed from the western side of Budapest, across the Danube and the Balaton-Tóalmás Line toward the SE, and is followed by a trend of fresh-brackish-saline water (Figs. 7 and 9). The hydraulic function of the Balaton-Tóalmás Line and the connected fault zones becomes more pronounced at this depth interval, as fluid potential anomalies can be observed around them. While the fluid potential field is almost the same with or without the data from the covering formations (Fig. 7a and b), significant differences in salinity could be recognized (Fig. 9a,b) comparing the two map versions. According to the salinity data of HSG1 AF and HSG2 AF(AT) (Fig. 9b) in the western (basically unconfined) part of the study area the fresh water body further extends eastward in relation to the overlying map (Fig. 8d), indicating the increasing extent and influence of the carbonates of HSG1 AF. On the other hand, looking at the differences between Fig. 9a and b, water salinity is generally higher within the confining formations over the whole study area.
As a result, in the western part of the study area the fresh water body of HSG1 AF and HSG2 AF-(AT) cover restricted areas by brackish waters, whereas in the eastern part saline waters fill up significantly larger areas (Fig. 9a).

\subsection{Flow pattern and effects of hydrostratigraphy in the deep confined area}

The hydraulic cross sections (Fig. 10) and the numerical simulation (Fig. 11) represents the deep confined part of the study area (Figs. 1c and 2). Down to $-500 \mathrm{~m}$ asl we can follow the effect of GDRGF also in the hydraulic sections (Fig. 10), as well as the change in the character of the water from dominantly fresh to saline beneath the penetration depth of GDRGF systems from dominantly fresh to saline, in accordance with the tomographic potential and salinity map series (Figs. 5-9). Below this elevation, significant underpressure evolves with depth, such as may be seen on the potential map of $-1000 \mathrm{~m}$ asl (Fig. 7) in the south of the BalatonTóalmás Line. The lowest pressures (or highest pressure deviations) are linked to the HSG3 AT, indicating regionally hampered downward flow from the Gödöllö Hills towards the highly permeable HSG1 AF. Accordingly, the thicker the HSG3 AT, the higher the negative pressure deviation within this and the underlying units is. The numerical simulation (Fig. 11) confirmed the flow field interpretation of the data-poor hydraulic sections (Fig. 10), and particularly the evolution of the regionally extensive underpressure in HSG3 AT, which influences the pressure conditions also in the basement carbonate aquifers (HSG1 AF and HSG2 AF(-AT)). As a result, this underpressured zone of the flow field represents a so- 
called potential sink characterized by limited water replenishment in the confined study area. In addition, the local hydraulic effects of faults can also be followed in the numerical simulation (Fig. 11) as they foster vertical fluid flow gradients. This phenomenon is also illustrated by the fluid potential anomalies along the fault zones on the tomographic potential maps (Figs. 6d and 7).

\subsection{Hydraulic connections between unconfined and confined carbonates}

Hydraulic processes between unconfined and confined carbonates were found to be influenced by GDRGF systems down to $-500 \mathrm{~m}$ asl based on systematic hydraulic and salinity data analyses. In agreement with the findings of Mádl-Szönyi and Tóth (2015; Figs. 6a, 8c and 9b), an asymmetric flow pattern was revealed, with different salinity pattern on the two sides of the Danube. In addition to our previous knowledge, this research clarifies the fluid potential field in 3D, based on subsequent slices of potentiometric surfaces. The discharging function of the Danube was demonstrated from the ground surface down to $0 \mathrm{~m}$ asl (Figs. 5 and $6 \mathrm{a}$ ). However, the location of discharge and recharge areas for different slices displays the asymmetric pattern of flow between 0 and $-500 \mathrm{~m}$ asl (Fig. $6 \mathrm{~b}$ and $\mathrm{c}$ ). This, namely the main discharging effect of the Danube in the $100-50 \mathrm{~m}$ asl potentiometric slice. The eastward through-flow below the Danube between 50 and $0 \mathrm{~m}$ asl elevation could also be seen in the local-scale study of Erhardt et al (2017 Fig. 7a and b) for the Buda Thermal Karst, Budapest. In the present study it also becomes clear that in the GDRGF field the area of through-flow is more pronounced compared to the areal extension of recharge and discharge areas. It highlights the theoretical findings of Mádl-Szőnyi and Tóth (2015) that the close to hydrostatic pressure condition (through-flow) is the most characteristic flow regime in these carbonate regions. This refers more to regional than local flow components and recharge controlled GDRGF in these systems, based on a numerical study by Haitjema and Mitchell-Bruker (2005). In summary, the western unconfined and eastern confined carbonate regions show hydraulic continuity, adjustment to the modern relief (Tóth, 2009) down to $0 \mathrm{~m}$ asl.

However, the lateral connection between the unconfined and confined systems is hydraulically blocked in the deeper $0-(-500)$ $\mathrm{m}$ asl elevation interval (Fig. $6 \mathrm{~b}$ and $\mathrm{c}$ ) by the NNW-SSE hydraulic ridge (at the Gödöllő Hills) and the hydraulic sink (presumably generated by the HSG3 AT) in the east of the Danube in Budapest. The latter also appears between $(-500)-(-1000) \mathrm{m}$ asl in the south of Budapest (Fig. 6d).

Under $-1000 \mathrm{~m}$ asl the fluid potential pattern (Fig. 7a and b) changes again, displaying a simple NW-SE through-flow in the study area. However, the decreasing potential values from the normal $120 \mathrm{~m}$ asl to $80-40 \mathrm{~m}$ asl, which are less than the presumed lowest value derived from recent topography, may reflect a deficit in the replenishment of the water towards the SE. The limited fluxes at this depth also appeared in the 2D flow simulation of Mádl-Szönyi and Tóth (2015) but with closed lateral boundaries and in the study of Havril et al. (2016) with inflow lateral boundaries. These simulations, however, were not connected to the deep confined part of the basin. The NW-SE through-flow is also well reflected in the salinity pattern by the NW-SE trending freshbrackish-saline water transition (Fig. 9). The through-flow under the Danube at this depth is limited due to low permeability MiddleLower Triassic and Permian formations (Fig. 2a). Another significant lateral barrier of flow may be the Balaton-Tóalmás Line (Fig. 2) along which the Pre-Cenozoic basement (HSG1 AF) subsides by about $1000 \mathrm{~m}$ in the south of the Line. The salinity change from brackish to saline across the Line clearly indicates the limited lateral communication across it.

\subsection{Relationships between siliciclastic confining layers and carbonate systems}

The vertical connectivity of carbonate aquifers (HSG1 AF, HSG2 $\mathrm{AF}(-\mathrm{AT})$ ) and confining layers via cross formational flow is obvious from the potentiometric slices (recharge and discharge areas) for that region of the study area where the existence of GDRGF systems could be proven (down to $-500 \mathrm{~m}$ asl) (Figs. 5, and $6 \mathrm{a}-\mathrm{c}$ ). Based on the Pre-Cenozoic basement maps (Fig. 2) and the hydrostratigraphic maps down to $-500 \mathrm{~m}$ asl (Fig. $4 \mathrm{a}-\mathrm{c}$ ) we can follow the degree of confinement of the HSG1-2 carbonate aquifers. In the eastern and southern parts of the study area the GDRGF systems evolves in the upper hydrostratigraphic units (HSG4 AF-AT and HSG5 AF-AT); consequently, they do not influence directly the deep confined carbonate aquifers.

Below $-500 \mathrm{~m}$ asl and particularly in the east of Budapest the GDRGF systems are underlain by an area regionally characterized by less than hydrostatic pressures (an underpressured regime), giving rise to downward vertical flow. However, the flux of the exchanging water may be low due to the low permeability of the confining layers (HSG3 AT). The Balaton-Tóalmás Line is a significant tectonic element in this context as well, because to its southeast the carbonate aquifers are covered by even thicker siliciclastic confining layers (Fig. 2). In addition, we can see very significant positive and negative fluid potential anomalies, which are connected to the Balaton-Tóalmás Line and the surrounding fault zones. These anomalies show the hydraulic compartmentalization of the system in this region and at these depths. The fluid potential values in these delineated blocks initiating vertical upward or downward communication between basement carbonates and confining layers are also reflected in the salinity distribution (Fig. 9a, See Fig. 12).

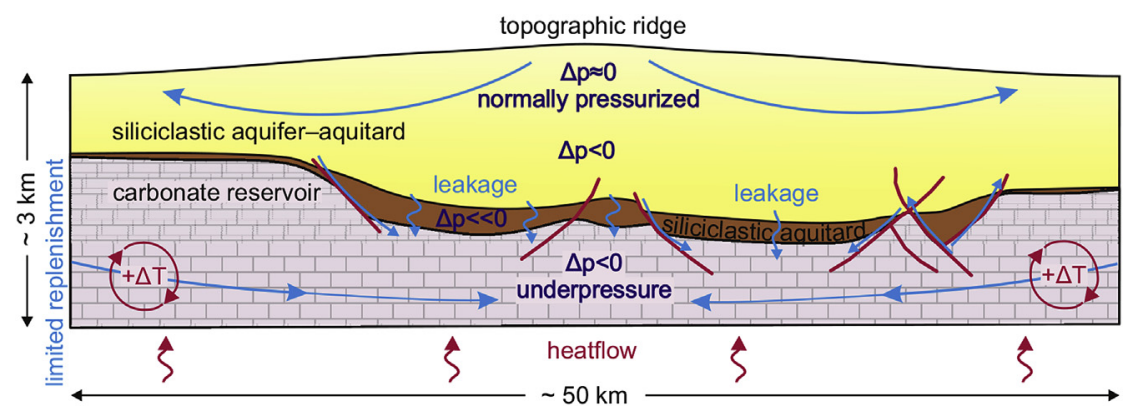

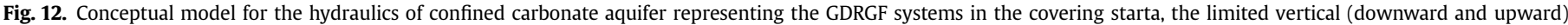

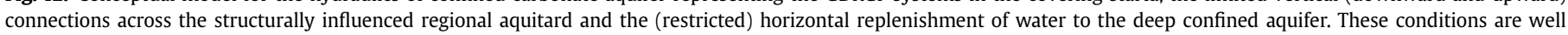
reflected in the pressure regimes: close to hydrostatic and less than hydrostatic. 
The revealed underpressure can be evaluated as the manifestation of the geologically transient flow field generated by the uplift of the Gödöllo" Hills over the last 4 million years (RuszkiczayRüdiger et al., 2005, 2007), which has resulted in decompaction due to erosional disequilibrium (unloading) (Mádl-Szőnyi et al., 2015). The consequent elastic rebound of the rock framework, could be responsible for the underpressure (Garven, 1995), in combination with the shortage of water replenishment caused by a regionally extensive aquitard (HSG3) lying beneath a gravitational recharge area. In agreement with theoretical studies, the greatest degree of underpressure was found within the aquitard characterized by the lowest permeability (Neuzil and Pollock, 1983; Corbet and Bethke, 1992). We can also see that confined carbonate aquifers in the SE of the Balaton-Tóalmás Line are tectonically separated from the uplifted unconfined areas. Therefore, this deep confined zone can be handled as hydraulically separated not only from the vertical but also the horizontal replenishment of water, and this also contributes to the subhydrostatic pressures. As a consequence of high heat flow and the basement carbonates this zone is also influenced by the buoyancy effect.

\section{Conclusion}

The results of the present study demonstrated that basin scale hydraulic approach is suitable for the understanding of flow pattern in confined carbonates. The research revealed different flow regimes in the study area depending on the position of basement carbonates and the thickness, hydraulic conductivity and heterogeneity of the covering layers. Consequently, the isolation of deep confined carbonates cannot be simply assumed without a comprehensive understanding of fluid dynamics.

In the upper sequence (down to $-500 \mathrm{~m}$ asl) of the study area, the existence of GDRGF systems with recharge and discharge areas was demonstrated. However, the lateral connection between the unconfined and confined systems is hydraulically hampered by the hydraulic ridge of the Gödölló Hills and the hydraulic sink generated by erosional decompaction and the existence of a regional aquitard unit (HSG3 AT) in the east of the Danube in Budapest. In the eastern and southern parts of the study area the GDRGF systems do not penetrate as far as the deep confined carbonate aquifers. Below (-500) $\mathrm{m}$ asl a NW-SE oriented through-flow can be observed, terminating in a regionally underpressured zone in the ESE part of the study area. The highest degree of underpressure has evolved in the regional aquitard (HSG3) is interpreted to be due to the erosional disequilibrium reflecting geologically transient flow field, as well as to the flow impeding effect of the aquitard itself. In the surroundings of the Balaton-Tóalmás Line, overpressured blocks defined by crosscutting faults were also found. In this region the overpressure and underpressure determine the vertical connections between siliciclastic confining layers and carbonate aquifers, also influencing hydrocarbon migration. The revealed flow regimes in the study area will be significant in the planning of any further geothermal exploration.

The salinity pattern also reflects the vertical and horizontal interaction of the siliciclastic cover formations and the carbonate aquifers in the distribution of the dominantly saline water of the confining units (HSG3-4) and the mostly fresh water of carbonates infiltrated into the (western) unconfined recharge areas. It may be concluded that confined carbonate aquifers are in lateral connection with unconfined regions and in vertical connection with the overlying siliciclastic layers, however, the degree of his connection is different. In other words, impermeable confining layers and hydraulically independent underlying carbonate aquifers cannot be unconditionally assumed to exist. The understanding of the interaction between them is a basic issue for the utilization of their resources such as hydrocarbons and thermal waters.

\section{Acknowledgements}

The authors would like to acknowledge the financial support of the National Research Development and Innovation Office (NKFIH 101356) in the research of the Buda Thermal Karst part of the study area. The background work to this study was conducted within the framework of R\&D cooperation between MOL and Eötvös Loránd University. The authors are very grateful to MOL for its data and financial support. The chemical database of the study was screened and the uncertainty of the data was evaluated with the assistance of Katalin Barkács. The contribution of Orsolya Sztanó is acknowledged in reviewing the geology section, while the discussion in the field of interpolation with József Kovács is also highly appreciated. Access to the Comsol Multiphysics software was provided by the Department of Geophysics and Space Science of Eötvös Loránd University, and particularly by Attila Galsa. The authors of the paper are grateful for the strict criticism of James Undershultz a reviewer of the paper and Hanneke Verweij the guest editor of the Special Issue, and also for the advices of Irén Varsányi in water chemical issues. Last, but not least the authors would like to thank the inspiration of József Tóth and his valuable comments regarding the title and abstract of the manuscript.

\section{References}

Allen, D.M., Bayer, P., Ferguson, G., Blum, P., 2014. Preface: hydrogeology of shallow thermal systems. Hydrogeology J. 22 (1), 1.

Bada, G., Horváth, F., Dövényi, P., Szafián, P., Windhoffer, G., Cloetingh, S., 2007. Present-day stress field and tectonic inversion in the Pannonian basin. Glob. Planet. Change 58 (1), 165-180.

Badics, B., Vetö, I., 2012. Source rocks and petroleum systems in the Hungarian part of the Pannonian Basin: the potential for shale gas and shale oil plays. Mar. Pet. Geol. 31 (1), 53-69.

Balázs, A., Matenco, L., Magyar, I., Horváth, F., Cloetingh, S., 2016. The link between tectonics and sedimentation in back-arc basins: new genetic constraints from the analysis of the Pannonian Basin. Tectonics 35 (6), 1526-1559.

Bauer, M., Tóth, T.M., Raucsik, B., Garaguly, I., 2016. Petrology and paleokarst features of the Gomba hydrocarbon reservoir (central Hungary). Cent. Eur. Geol. 59 (1-4), 28-59.

Boncz, L., 2004. Zárójelentés a 103. Gödöllő Kutatási Területen Végzett CH-kutatási Tevékenységröl. Final Report of the Petroleum exploration activity on the Gödöllö 103. research area. Hungarian Oil Company (MOL).

Boncz, L., Sőreg, V., Balázs, E.-N., Eszes, I.-N., Klemenik, R.B., Lux, M., Pusztai, J., Szabóné László, A., Szászfai, J., Gyergyói, L., Mészáros, V.C., Zsuppán, G., Kovács, A., Milánkovich, A., Hajdu, Á., Kaszvinszki, R., Spitzmüller, Á., Tóth, J., Vargáné Tóth, I., Vida, E., 2012. Zárójelentés a 125. Jászberény Területen Végzett Szénhidrogénkutatási Tevékenységről. Final Report of the Petroleum exploration activity on the Jászberény 125. research area. Hungarian Oil Company, Budapest.

Buda, G., 1995. Correlation of Middle European Variscan Granitoids. Habil, ELTE, Budapest.

Báldi, T., Báldi-Beke, M., 1985. The evolution of the Hungarian Paleogene basins. Acta Geol. Hung. 28 (1-2), 5-28.

Bérczi, I., Phillips, R.L., 1985. Processes and depositional environments within Neogene deltaic-lacustrine sediments, Pannonian Basin, southeast Hungary. Geophys. Trans. 31 (1-3), 55-74.

Corbet, T.F., Bethke, C.M., 1992. Disequilibrium fluid pressures and groundwater flow in the Western Canada sedimentary basin. J. Geophys. Res. Solid Earth 97 (B5), 7203-7217.

Csontos, L., Nagymarosy, A., Horváth, F., Kovac, M., 1992. Tertiary evolution of the Intra-Carpathian area: a model. Tectonophysics 208 (1), 221-241.

Csontos, L., Vörös, A., 2004. Mesozoic plate tectonic reconstruction of the Carpathian region. Palaeogeography, Palaeoclimatology, Palaeoecology 210 (1), 1-56.

Czauner, B., Mádl-Szőnyi, J., 2013. Regional hydraulic behavior of structural zones and sedimentological heterogeneities in an overpressured sedimentary basin. Mar. Pet. Geol. 48, 260-274.

Deming, D., 2002. Introduction to Hydrogeology. McGraw-Hill College, New York.

Dolton, G.L., 2006. Pannonian Basin Province, Central Europe (Province 4808) Petroleum Geology (Total Petroleum Systems and Petroleum Resource Assessment, Reston, Virginia).

Dövényi, P., Horváth, F., 1988. A review of temperature, thermal conductivity, and heat flow data from the Pannonian Basin. Pannonian Basin 45, 195-233.

Erhardt, I., Ötvös, V., Erőss, A., Czauner, B., Simon, S., Mádlné Szőnyi, J., 2017. Hydraulic evaluation of the hypogenic karst area in Budapest (Hungary). 
Hydrogeology J. http://dx.doi.org/10.1007/s10040-017-1591-3.

Eröss, A., 2010. Characterization of Fluids and Evaluation of Their Effects on Karst Development at the Rózsadomb and Gellért Hill, Buda Thermal Karst, Hungary. PhD Dissertation. Eötvös Loránd University, Budapest.

Gajdos, I., Pap, S., Somfai, A., Völgyi, L., 1983. Az alföldi pannóniai (sl) képzõdmények litosztratigráfiai egységei (Lithostratigraphic units of the Pannonian sl formations in the Hungarian Plain).-MÁFI kiadvány. Magyar Állami Földtani Intézet (Hungarian Geological Survey) 70, Budapest.

Garamhegyi, T., 2014. Kúthidraulikai Vizsgálatok Analitikus És Numerikus Értékelése És Összehasonlító Elemzése Budapest Tágabb Környezetében. MSc, ELTE, Budapest.

Garven, G., 1995. Continental-scale groundwater flow and geologic processes. Annu. Rev. Earth Planet. Sci. 23 (1), 89-117.

Goldscheider, N., Mádl-Szőnyi, J., Erőss, A., Schill, E., 2010. Review: thermal water resources in carbonate rock aquifers. Hydrogeology J. 18 (6), 1303-1318.

Haas, J., 2012. Geology of Hungary. Springer Science and Business Media, Budapest, Hungary.

Haas, J., Budai, T., Csontos, L., Fodor, L., Konrád, G., 2010. Magyarázó Magyarország pre-kainozoos földtani térképéhez 1:500 000. In: Hungary, G.a.G.I.o. (Ed.), Explanation to the Pre-cenozoic Geological Map of Hungary. Geological and Geophysical Institute of Hungary, Budapest.

Haas, J., Korpás, L., Török, Á., Dosztály, L., Góczán, F., Hámor-Vidó, M., OraveczScheffer, A., Tardi-Filácz, E., 2000. Felső-triász medence-és lejtőfáciesek a Budaihegységben a Vérhalom téri fúrás vizsgálatának tükrében (Upper Triassic basin and slope facies in the Buda Mts. based on study of core drilling Vérhalom tér, Budapest). Földtani Közlöny 130 (3), 371-421.

Haitjema, H.M., Mitchell-Bruker, S., 2005. Are water tables a subdued replica of the topography? Groundwater 43 (6), 781-786.

Havril, T., Molson, J., Mádl-Szönyi, J., 2016. Evolution of fluid flow and heat distribution over geological time scales at the margin of unconfined and confined carbonate sequences-A numerical investigation based on the Buda Thermal Karst analogue. Mar. Pet. Geol. 78, 738-749.

Horváth, F., 2007. The Geo-dynamics of the Pannonian Basin (In Hungarian). DSc Theses. ELTE, Budapest.

Horváth, F., Bada, G., 2004. Atlas of the Present-day Geodynamics of the Pannonian Basin: Euroconform Maps with Explanatory Text. Dept. of Geophysics, ELTE, Budapest.

Horváth, F., Cloetingh, S., 1996. Stress-induced late-stage subsidence anomalies in the Pannonian basin. Tectonophysics $266(1-4), 287-300$.

Horváth, F., Royden, L., 1981. Mechanism for the formation of the intra-Carpathian basins: a review. Earth Evol. Sci. 1 (3-4), 307-316.

Hubbert, M.K., 1940. The theory of ground-water motion. J. Geol. 48 (8, Part 1), 785-944.

Hunt, J.M., 1990. Generation and migration of petroleum from abnormally pressured fluid compartments (1). AAPG Bull. 74 (1), 1-12.

Institute, E.S.R., 2014. ArcGIS Desktop Help 10.2 Geostatistical Analyst.

Juhász, G., Pogácsás, G., Magyar, I., Vakarcs, G., 2007. Tectonic versus climatic control on the evolution of fluvio-deltaic systems in a lake basin, Eastern Pannonian Basin. Sediment. Geol. 202 (1), 72-95.

Kele, S., Scheuer, G., Demény, A., Shen, C.-C., Chiang, H.-W., 2011. A Rózsadomb (Budapest) édesvízi mészköveinek U/Th sorozatos kormeghatározása és stabilizotóp-geokémiai vizsgálata (U/Th dating and stable isotope geochemical investigation of the travertines of the Rózsadomb (Budapest)). Földtani Közlöny 141 (2), 445-468.

Kiss, K., Bujdosó, I., Milánkovich, A., Pápa, A., Soós, S., Szentgyörgyi, K., Tóth, Z., Tóthné Medvei, Z., Vargáné Tóth, I., Tirpák, I., 1999. Final Report of the Petroleum Exploration on the SW Part of the Paleogen Basin. Hungarian Oil Company (MOL), Budapest.

Kovács, S., Buda, G., Haas, J., Brezsnyánszky, K., Harangi, S., 2010. Tectonostratigraphic terranes and zones juxtaposed along the Mid-Hungarian Line: their contrasting evolution and relationships. Cent. Eur. Geol. 53 (2-3), 165-180.

Körössy, L., 2004. Geological results of oil and gas exploration in the North Hungarian Paleogene Basin).-Általános Földtani Szemle. Az Észak-magyarországi Paleogén Medence Kőolaj-és Földgázkutatásának Földtani Eredményei, vol. 28, pp. 7-119.

Leél-Ôssy, S., 1995. A Rózsadomb és környékének különleges barlangjai (Particular caves of the Rózsadomb Area). Földtani Közlöny 125 (3-4), 363-432.

Magyar, I., Geary, D.H., Müller, P., 1999. Paleogeographic evolution of the late Miocene Lake Pannon in Central Europe. Palaeogeography, palaeoclimatology. Palaeoecology 147 (3), 151-167.

Marosi, S., Somogyi, S., 1990. Magyarország kistájainak katasztere II. In: Intézet, M.F.K. (Ed.), Cadastres of the Micro Regions of Hungary. MTA Földrajztudományi Kutató Intézet, Budapest.

Martinecz, A., 2014. Hidrosztratigráfiai Értékelés És Áramkép Szimuláció a Budai Termálkarszton. Hydrostratigraphic distribution and groundwater flow simulation in the Buda Thermal Karst. ELTE, Budapest.

Mersich, I., 2000. Magyarország Éghajlati Atlasza (Climate Atlas of Hungary). Hungarian Meteorological Service, Budapest.

Mádlné Szőnyi, J., Czauner, B., Erőss, A., Simon, S., 2013. Karbonátos És Csatlakozó Üledékes Medenceterületek Fluidumdinamikai Összefüggéseinek Vizsgálata a Szénhidrogén Kutatás Hatékonyságának Javítása Érdekében a Paleogénmedencében - Zárójelentés. Investigation of fluid-dynamic connection of carbonate and adjoining basin in hydrocarbon exploration purposes - Final Report. Hungarian Oil Company, Budapest.

Mádl-Szőnyi, J., Pulay, E., Tóth, Á., Bodor, P., 2015. Regional underpressure: a factor of uncertainty in the geothermal exploration of deep carbonates, Gödöllö Region, Hungary. Environ. Earth Sci. 74 (12), 7523-7538.

Mádl-Szőnyi, J., Tóth, Á., 2015. Basin-scale conceptual groundwater flow model for an unconfined and confined thick carbonate region. Hydrogeology J. 23 (7) 1359-1380.

Mádl-Szőnyi, J., Simon, S., 2015. Involvement of preliminary regional fluid pressure evaluation into the reconnaissance geothermal exploration-example of an overpressured and gravity-driven basin. Geothermics 60, 156-174.

Neuzil, C., Pollock, D., 1983. Erosional unloading and fluid pressures in hydraulically “; tight”; rocks. J. Geol. 91 (2), 179-193.

Papp, F., 1942. Budapest Meleg Gyógyforrásai. Warm medicinal springs of Budapest, p. 252 (Budapest).

Poros, Z., Mindszenty, A., Molnár, F., Pironon, J., Győri, O., Ronchi, P., Szekeres, Z. 2012. Imprints of hydrocarbon-bearing basinal fluids on a karst system: mineralogical and fluid inclusion studies from the Buda Hills, Hungary. Int. J. Earth Sci. 101 (2), 429-452.

Royden, L.H., Horváth, F., Burchfiel, B., 1982. Transform faulting, extension, and subduction in the Carpathian Pannonian region. Geol. Soc. Am. Bull. 93 (8), $717-725$.

Rumpler, J., Horváth, F., 1988. Some representative seismic reflection lines from the Pannonian Basin and their structural interpretation. Pannonian Basin, a study basin Evol. AAPG Mem. 45, 153-169.

Ruszkiczay-Rüdiger, Z., Dunai, T., Fodor, L., Bada, G., Leél-Őssy, S., Horváth, E., 2005 A negyedidőszaki függöleges kéregmozgások számszerűsítése a Duna völgyében a korábbi kronológiai adatok és új, kozmogén 3He kitettségi kor mérések alapján (Quantifíng of Quaternary vertical movements of litosphere in the Duna Valley based on archive chronological and new 3He exposure data). Földtani Közlöny 135 (3), 373-403.

Ruszkiczay-Rüdiger, Z., Fodor, L., Horváth, E., 2006. Neotectonic and landscape evolution of the Gödöllö Hills, central Pannonian Basin, Hungary. Geolines 20, $116-118$.

Ruszkiczay-Rüdiger, Z., Fodor, L.I., Horváth, E., 2007. Neotectonics and quaternary landscape evolution of the Gödöllö Hills, Central Pannonian Basin, Hungary. Glob. Planet. Change 58 (1), 181-196.

Schmid, S.M., Bernoulli, D., Fügenschuh, B., Matenco, L., Schefer, S., Schuster, R. Tischler, M., Ustaszewski, K., 2008. The Alpine-Carpathian-Dinaridic orogenic system: correlation and evolution of tectonic units. Swiss J. Geosci. 101 (1), 139-183.

Schwartz, F.W., Zhang, H., 2003. Fundamentals of Ground Water. Wiley, New York.

Sztanó, O., Kováč, M., Magyar, I., Šujan, M., Fodor, L., Uhrin, A., Rybár, S., Csillag, G. Tökés, L., 2016. Late Miocene sedimentary record of the Danube/Kisalföld Basin: interregional correlation of depositional systems, stratigraphy and structural evolution. Geol. Carpathica 67 (6), 525-542.

Sztanó, O., Szafián, P., Magyar, I., Horányi, A., Bada, G., Hughes, D.W., Hoyer, D.L. Wallis, R.J., 2013. Aggradation and progradation controlled clinothems and deep-water sand delivery model in the Neogene Lake Pannon, Makó trough, Pannonian Basin, SE Hungary. Glob. Planet. Change 103, 149-167.

Tari, G., Báldi, T., Báldi-Beke, M., 1993. Paleogene retroarc flexural basin beneath the Neogene Pannonian Basin: a geodynamic model. Tectonophysics 226 (1) 433-455.

Tari, G., Horváth, F., Rumpler, J., 1992. Styles of extension in the Pannonian Basin Tectonophysics 208 (1), 203-219.

Tóth, J., 1962. A theory of groundwater motion in small drainage basins in central Alberta, Canada. J. Geophys. Res. 67 (11), 4375-4388.

Tóth, J., 1963. A theoretical analysis of groundwater flow in small drainage basins J. Geophys. Res. 68 (16), 4795-4812.

Tóth, J., Maccagno, M.D., Otto, C.J., Rostron, B.J., 1991. Generation and migration of petroleum from abnormally pressured fluid compartments: discussion (1) AAPG Bull. 75 (2), 331-335.

Tóth, J., 1995. Hydraulic continuity in large sedimentary basins. Hydrogeology J. 3 (4), 4-16.

Tóth, J., 2009. Gravitational Systems of Groundwater Flow: Theory, Evaluation, Utilization. Cambridge University Press.

Uhrin, A., 2011. Lake-level Changes and Their Controlling Factors in Some Subbasins of the Late Miocene Lake Pannon. ELTE Institute of Geography and Earth Sciences.

Uhrin, A., Sztanó, O., 2007. Reconstruction of Pliocene fluvial channels feeding Lake Pannon (Gödöllö Hills, Hungary). Geol. Carpathica 58 (3), 291-300.

Verweij, H.M., Simmelink, H.J., Underschultz, J., Witmans, N., 2012. Pressure and fluid dynamic characterisation of the Dutch subsurface. Neth. J. Geosci. 91 (4) 465-490.

Wein, G., Konda, J., Vállalat, K., Intézet, M.Á.F., 1977. A Budai-hegység Tektonikája, Földtani Térképek (Tectonics of the Buda Hills, Geological Maps). Magyar Állami Földtani Intézet, Budapest.

Zilahi-Sebess, L., 2011. In: Zilahi-Sebess, L. (Ed.), E2. Geotermikus Rezervoárok Vizsgálata, Potenciális Területek Lehatárolása És Koncessziós Pályázatra Alkalmas Területek Kijelölése (Investigation of Geothermal Reservoirs, Delienation of Potential Geothermal Areas). ELGI-MÁFI, Budapest, p. 61.

Zilahi-Sebess, L., Gyuricza, G., 2012. Gödöllő Terület: Komplex Érzékenységi És Terhelhetőségi Vizsgálati Tanulmány. Gödöllö Terület Geotermikus Koncessziós Jelentése (Gödöllő Area: Complex Sensitivity and Load Capacity Studies. Geothermal Report of Gödöllő Area). Geological and Geophysical Institute of Hungary, Budapest, p. 163.

Zimmerman, W.B. 2006. Multiphysics Modeling with Finite Element Methods (Series on Stability, Vibration and Control of Systems, Serie). World Scientific Publishing Co., Inc. 